\title{
D IENES Y ESPACIOS DE PRIVANZA EN EL D CASTILLO Y PALACIO DEL DUQUE DE LERMA EN DÉNIA ${ }^{1}$
}

\author{
ÀNGEL CAMPOS-PERALES \\ Departament d'Història de l'Art. Universitat de València \\ Angel.Campos-Perales@uv.es
}

\begin{abstract}
Resumen: Francisco Gómez de Sandoval y Rojas (1553-1625), V marqués de Dénia y I duque de Lerma, emprendió una importante transformación de su palacio valenciano de Dénia desde no mucho antes de 1611 y hasta los comienzos de los años 20 del siglo XVII. Las reformas constructivas y las labores de equipamiento de la casa, que se intensificaron entre 1616 y 1618, estuvieron destinadas a dar alojamiento digno al rey Felipe III en la frustrada visita real a Dénia para la celebración de Cortes del Reino de Valencia. Así, a partir de una vista desconocida de Dénia y documentación de archivo inédita pretendemos redefinir las cronologías de unas arquitecturas prácticamente desaparecidas y poco estudiadas, reconstruir los espacios que las conformaban y determinar la sistematización de bienes que se custodiaron en su interior y exterior.
\end{abstract}

Palabras clave: duque de Lerma / Felipe III / castillo de Dénia / pintura / Juan de Chavarria / Carlos Coloma / mesas de piedras duras.

\section{GOODS AND SPACES OF FAVORITISM IN THE CASTLE AND PALACE OF THE DUQUE OF LERMA IN DÉNIA}

Abstract: Francisco Gómez de Sandoval y Rojas (1553-1625), V Marquis of Dénia and I Duke of Lerma, undertook an important transformation of his Valencian palace in Dénia from not long before 1611 and until the beginning of the 20's of the 17th century. The construction reformations and the equipping of the palace, which intensified between 1616 and 1618, were designed to provide a dignified accommodation for King Philip III in the frustrated royal visit to Dénia for the celebration of Cortes of the Kingdom of Valencia. Thus, from an unknown view of Dénia as well as unpublished archive documentation, we intend to redefine the chronologies of these practically disappeared architectures, reconstruct the spaces that configured them and determine the systematization of goods that were guarded inside and outside.

Key words: Duke of Lerma / Philip III / castle of Dénia / painting / Juan de Chavarria / Carlos Coloma / hardstone tabletops.

El 18 de diciembre de 1611 el cronista cortesano Luis Cabrera de Córdoba escribía en Madrid lo siguiente: "se ha dicho de ir [la Corte] a Dénia, adonde ha muchos días desea ir S.M., para ver dos cuartos que el Duque ha fabricado en aquella fortale- za para aposentar los Reyes cuando fueran allá, que dicen son mucho de ver, porque los ha hecho el Duque con mucha costa y curiosidad". ${ }^{2}$ El testimonio de Cabrera de Córdoba es de una importancia capital por varias razones. Por una parte, pone

\footnotetext{
* Fecha de recepción: 15 de abril de 2019 / Fecha de aceptación: 21 de octubre de 2019.

1 El autor ha contado con una ayuda de Formación de Personal Universitario (FPU) del Ministerio de Ciencia, Innovación y Universidades del Gobierno de España para la realización del presente trabajo. Mis investigaciones sobre el duque de Lerma se remontan al curso académico 2016-2017, cuando en el marco de una beca de investigación en el Museo del Prado, Mercedes Gómez-Ferrer y Miguel Falomir, actuales directores de mi tesis doctoral, me sugirieron abordar el estudio del coleccionismo nobiliario en el Reino de Valencia durante los reinados de Felipe II y Felipe III. Fruto de aquellas conversaciones son ahora estas líneas, que no habrían sido posibles sin sus provechosos comentarios y estímulos iniciales.
}

2 CABRERA DE CÓRDOBA, Luis, 1857, p. 457. 
de relieve la clara voluntad del monarca de volver a Dénia, cabeza de los estados valencianos del V marqués de Dénia y I duque de Lerma y escenario efímero de la Corte ya en 1599 y 1604; por otra, se trata de la primera noticia conocida del proceso de transformación del castillo y palacio del privado, sufragado sirviéndose de las finanzas reales y ducales, con el fin de acondicionarlos según las necesidades y predilecciones de Felipe III. Aunque la pretendida visita real nunca volvería a producirse, las obras de acondicionamiento de esta residencia se prolongaron en el tiempo desde no mucho antes de 1611 y hasta los comienzos de los años 20 de esta centuria. La intención del presente estudio no es solamente redefinir las cronologías de unas arquitecturas parcialmente destruidas y poco examinadas, sino también reconstruir los espacios que las articulaban y dar a conocer la sistematización de bienes que se custodiaban en su interior y exterior.

Asimismo, la materialización de dichas reformas en el palacio valenciano del duque de Lerma no era una cuestión ignorada por la historiografía, ya que desde al menos 1643, año en que Marco Antonio Palau informaba de la renovación del palacio por parte del duque "añadiéndole un quarto y galería" y hasta 2015, con los estudios de Josep Ivars, se había examinado escuetamente tal legado constructivo. ${ }^{3}$ Es más, todas las obras y mejoras llevadas a cabo por Lerma tanto en el palacio como en el castillo fueron cuantificadas en su testamento de 1625, donde aseguró que "en la mi ciudad de Dénia, la cassa prinçipal que e hecho en el castillo" y, más tarde, "en el castillo de Dénia", se había gastado "seis quenttos y quattroçienttas y diez mill maravedís". ${ }^{4}$ Pero realmente, ¿cómo cristalizaron tales gastos? ¿Cuál fue el grado de participación de la hacienda pública en tales mejoras arquitectónicas? ¿Cúanto se implicaron personalmente el monarca y el duque en tales cuestiones? Estas serán algunas de las preguntas que trataremos de responder en las siguientes líneas.

Más escasos todavía son los estudios sobre coleccionismo y patronazgo artístico de Lerma en tierras valencianas, limitándose a cuestiones puntuales de obras muy concretas, ${ }^{5}$ o enmarcados en obras de carácter más global y destinadas a rememorar los gratos recuerdos de su mandato en Dénia. ${ }^{6}$ Como ya hemos puesto de manifiesto en repetidas ocasiones, la historiografía acerca de la privanza del duque de Lerma ha gravitado frecuentemente en torno a un eje espacio-temporal muy concreto, es decir, analizando el alcance de su influencia política, cortesana y cultural en el medio castellano que integraban las ciudades de Madrid, Valladolid y Lerma y durante sus casi veinte años de acceso al poder (1599-1618). De este

\footnotetext{
3 "Mandó [el duque de Lerma] renovar el palacio añadiéndole un quarto, y galería, y fortificar el Castillo de manera, que oy es uno de los más vistosos edificios, y más fuertes de la costa de España, obra que costó 50 mil ducados". PALAU, Marco Antonio, 1975 [1643], pp. 158-159. Ya en el siglo XIX, parafraseando a Palau, Roque Chabás apuntaría: "La plaga de estos mares eran en el siglo XVI los corsarios africanos [...]. Para prevenirse bien a la defensa mandó [el duque de Lerma] renovar el castiIlo, fortificándole y haciendo varias obras en el Palacio, de modo que quedó uno de los mejores de la costa de España". CHABÁS, Roque, 1876, tomo II, p. 123. Recientemente Josep Ivars ha atribuido la renovación total del palacio a cualquiera de los muchos arquitectos que trabajaron para el duque en la villa de Lerma, y entre estos, principalmente a Francisco de Mora, según evidentes paralelismos formales. IVARS, Josep, 2015, pp. 36-37. Véase también nuestro reciente trabajo, en el que aportamos documentación inédita acerca del legado constructivo del duque de Lerma en el marquesado de Dénia, poniendo especial énfasis en el encargo de su estatua marmórea realizada en Génova. CAMPOS-PERALES, Àngel, 2018a, pp. 395-410.

${ }^{4}$ GARCÍA, Eugenio; SEBASTIÁN, Ramón, 1983, pp. 282 y 288.

${ }^{5}$ Es el caso de la Tortuga laúd de Pedro Juan Tapia (1597) del Museo del Prado, una pintura presumiblemente enviada por el duque de Lerma al rey Felipe II. PÉREZ SÁNCHEZ, Alfonso E., 1991, pp. 7-11. Como se apunta en la cartela incluida en el cuadro, este peregrino animal fue tomado en la almadraba de Dénia el 28 de agosto de 1597. Hasta ahora no se había puesto en relación con la biografía de este pintor una noticia de 1602 según la cual un tal "Juan de Tapia" se encontraba decorando y embelleciendo salones de la Casa Real de Valladolid, anteriormente del duque de Lerma, junto a pintores como Bartolomé Carducho y Fabricio Castelo. Véase MARTí Y MONSÓ, José, 1898-1901, p. 605 y CERVERA VERA, Luis, 1967a, p. 136. A manera de hipótesis, podría tratarse del mismo artista documentado durante el virreinato del duque de Lerma (1595-1597) en el Palacio del Real de Valencia, trabajando como pintor y arquitecto para el rey, y en otras noticias de años anteriores en esta misma ciudad. Véase GÓMEZ-FERRER, Mercedes, 2012, pp. 170 y ss. y ARCINIEGA GARCíA, Luis, 2005-2006, pp. 148-150. Si realmente se estableció en la Corte después de su etapa valenciana, cabría sopesar la posibilidad de que fuese el Pedro Juan de Tapia documentado en 1612 como aparejador de las obras de Aranjuez, tasando pinturas de Patricio Cajés y otros pintores en el Pardo. GÓMEZ-FERRER, Mercedes, 2012, p. 172.

${ }^{6}$ Por ejemplo, entre el 17 de diciembre de 2004 y el 20 de febrero de 2005 tuvo lugar en Dénia la exposición El Rei a Dénia. Felip III i la Fundació de Ntra. Sra. de Loreto, comisariada por Josep A. Gisbert, arqueólogo municipal, cuyo entusiasmo por el estudio que aquí presentamos y disponibilidad a la hora de prestarnos sus recursos han sido fundamentales para la elaboración del mismo. Véanse también los trabajos de Rosa Seser, conmemorando, por una parte, el cuarto centenario del Convento de las Agustinas de Dénia y, por otra, el cuarto centenario de la concesión del título de ciudad a este municipio. Véase especialmente: SESER, Rosa, 2013.
} 
modo, con los nuevos datos aportados queremos paliar parcialmente dichas carencias y ponderar la relevancia de unas noticias artísticas que enriquecen, con todo, la ya de por sí copiosa literatura en torno al privado de Felipe III. El primero de los epígrafes en los que se estructura esta investigación tiene como objeto el análisis de las fuentes visuales del castillo y palacio de Dénia, aquí manejadas como soporte de estudio adicional a la información documental que ofrecen textos y vestigios arquitectónicos y que ulteriormente iremos desgranando.

\section{Imágenes del castillo y palacio de Dénia y una vista inédita de la ciudad}

[Dénia] es población de más de quinientas casas. Está muy fuerte, bien torreada, y murada, tiene un buen castillo muy proveído de tiros, municiones, y armas, y de todo lo necesario para su defensa. [...] La fortaleza es muy capaz, y tiene mucho aposento, como vio Vuestra Majestad el año pasado de mil y quinientos y noventa y nueve estando aposentado en él con la reina nuestra señora y antes con la señora infante doña Isabel, y con el señor archiduque Alberto, su marido. Que fue la mayor honra en que jamás se podrá ver Dénia. Es el puerto de Dénia muy grande, muy seguro, muy abrigado y, a dicho de los que lo entienden bien, de los buenos que hay en el Mediterráneo, y de mayor concurso de bajeles de Levante y Poniente. ${ }^{7}$

¿Qué aspecto tenían el castillo y aquella casa principal del duque de Lerma que vio Felipe III en su visita de 1599 a Dénia con motivo de las dobles bodas reales celebradas en Valencia? Las palabras de Salazar de Mendoza describían una fortaleza preparada para afrontar cualquier tipo de amenaza exterior y aposentar convenientemente al séquito real en sus extraordinarias jornadas de 1599 y 1604. Es decir, a la capacidad defensiva del castillo se sumaba la disponibilidad de un palacio que podía dar alojamiento digno a reyes y cortesanos. Sin embargo, creemos que entre aquellos "muchos aposentos" que lo componían no se encontraban todavía los cuartos reales y galería que tiempo después Lerma erigiría. Así, aunque en otras investigaciones se había apuntado tal posibilidad, no existe evidencia alguna para fechar el grueso de las obras llevadas a cabo por el duque en

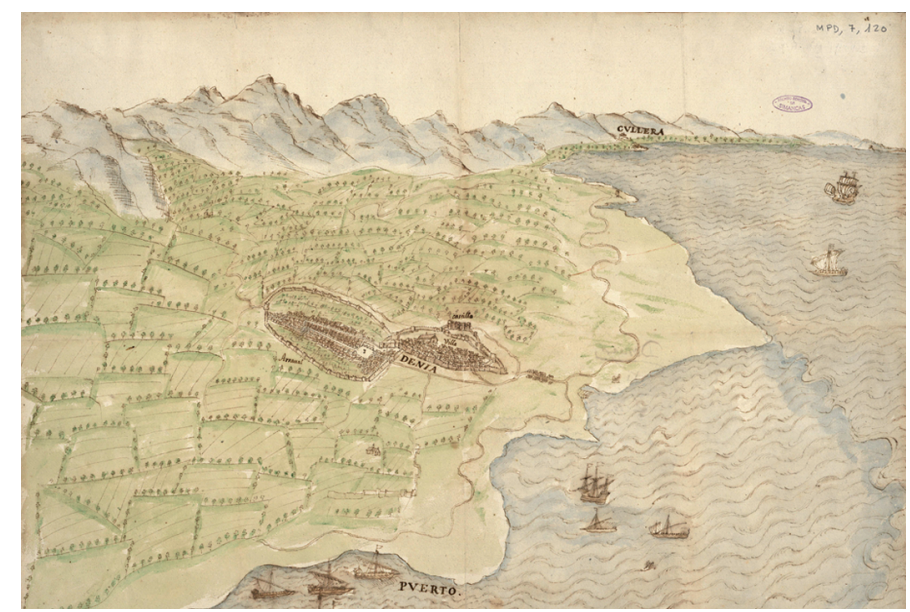

Fig. 1. Plano en perspectiva de la Plaza de Dénia y de sus alrededores, 1575. Archivo General de Simancas, MPD, 07, 120.

la antigua construcción medieval durante su etapa como virrey de Valencia (1595-1597), en los años previos a la primera visita real. ${ }^{8}$ Por lo tanto, las hechuras del castillo y palacio en 1599 y 1604 no diferirían demasiado de lo ilustrado en la primera vista conocida de esta ciudad costera del Reino de Valencia, el Plano en perspectiva de la Plaza de Dénia y de sus alrededores (fig. 1) de época del virrey Vespasiano Gonzaga (1575). En este plano, el urbanismo de Dénia quedaba definido por una serie de ámbitos: la villa, el arrabal, el incipiente barrio portuario, el doble puerto y el castillo, construido sobre la colina natural que se eleva junto a la costa. ${ }^{9}$ Por lo que atañe a este último, se representó el frente meridional del antiguo palacio medieval, en parte idealizado pero con los cinco torreones circulares que lo reforzaban y que todavía hoy parcialmente se conservan. En el centro de este lienzo del palacio se reprodujo el acceso al mismo, una apertura que más tarde, con la intensa remodelación impulsada por Lerma, se articularía con la escalera monumental en forma de $T$ invertida. Asimismo, en el frente oriental de la residencia, donde tiempo después se levantarían los nuevos aposentos reales, se vislumbran unas ventanas con vistas al mar que posteriormente, suponemos, quedarían cegadas.

\footnotetext{
7 Descendencia de Sandoval en elogios, Pedro Salazar de Mendoza, Biblioteca Nacional de España, Madrid (BNE), ms. 3.277, ff. 353r-353v. El pasaje completo fue citado por Bernardo J. García García en su estudio sobre la jornada valenciana de Felipe III en Dénia en 1599, consultable en GARCÍA GARCÍA, Bernardo J., 2004, p. 48.

8 IVARS, Josep, 2015, p. 36 y CAMPOS-PERALES, Àngel, 2018a, p. 397.

9 Sobre esta vista aérea de la ciudad de Dénia, el estudio e interpretación más recientes son de Josep Ivars, véase IVARS, Josep, 2015, pp. 31-33.
} 


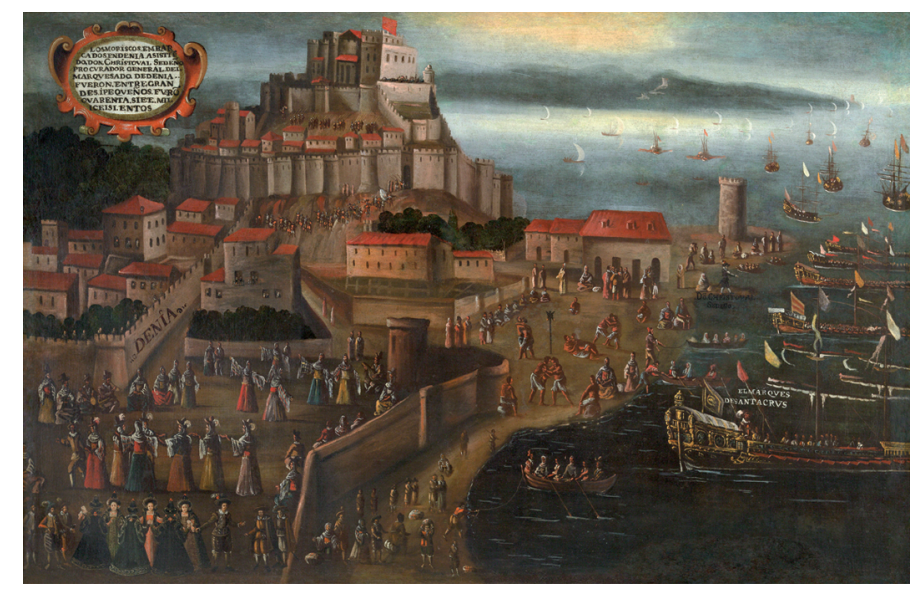

Fig. 2. Embarco de los moriscos en el puerto de Dénia, Vicent Mestre, 1612-1613. Colección de la Fundación Bancaja, València.

Desde esta fecha significativa de 1575 de la primera vista panorámica de Dénia -Lerma tomó posesión del marquesado de Dénia en 1574- y hasta la siguiente conocida, el cuadro del Embarco de los moriscos en el puerto de Dénia (1612-1613) (Fig. 2), transcurrió un largo lapso de tiempo, casi cuarenta años en los que el duque habría podido planificar con detenimiento el conjunto de actuaciones que materializaría en su casa principal. Primeramente, que pueda datarse dicha pintura entre los años 1612 y 1613, cuando la alteración del palacio ya ha- bía comenzado, es de una importancia trascendental. La documentación publicada por Jesús Villalmanzo en torno a esta obra y la serie de La expulsión de los moriscos del Reino de Valencia recogía una miscelánea de pagos entre noviembre de 1612 y diciembre de 1614 por los que ciertos pintores se comprometían a ejecutar diferentes lienzos sobre los embarcos en Valencia, Alacant, Dénia y Vinaròs y las rebeliones en las sierras de Cortes y Laguar. ${ }^{10}$ Por lo que respecta al cuadro de Dénia, la documentación atestigua que fue Vicent Mestre el pintor escogido para realizarlo. Según Villalmanzo, este comenzó a pintarlo a finales de 1612, ya que el 20 de diciembre de ese mismo año se pagaron 100 reales al patrón Roque Segarra por llevar a Dénia a "un pintor per a pintar una planta del port de Dénia", presumiblemente Vicent Mestre. ${ }^{11}$ Una vez tomadas del natural las referencias necesarias para componer la vista de Dénia, Mestre empezaría el cuadro cobrando un adelanto de 25 libras. La pintura fue terminada y tasada antes del 30 de marzo de 1613, cuando se le abonó el resto del montante, 866 reales casteIlanos. ${ }^{12}$ Además, otros pagos posteriores de finales de 1614 certifican que Mestre pintó una ulterior versión del Embarco de los moriscos en el puerto de Dénia para ser enviada a Madrid. Por lo tanto, desconocemos si la versión conservada actualmente en la Fundación Bancaja de Valencia es la original o la mencionada copia realizada a posteriori. $^{13}$

10 VILLALMANZO, Jesús, 1997, pp. 34-69. Véase también el apéndice documental en pp. 70-105. Aunque se creía que el destinatario de dicha serie era Felipe III, Yolanda Gil ha podido demostrar en un reciente estudio que realmente fue realizada para Rodrigo Calderón con el fin de convertir el encargo en una colección de tapices nunca llevada a cabo. GIL SAURA, Yolanda, 2018, pp. 133-153.

11 Véase el documento 6 del apéndice documental. VILLALMANZO, Jesús, 1997, p. 73. Sobre el pintor Vicent Mestre pueden consultarse las notas biográficas que recopila Villalmanzo. VILLALMANZO, Jesús, 1997, pp. 42-43. En otro orden de cosas, queremos aportar aquí un documento inédito sobre este pintor, importante para definir su personalidad artística y conocer sus intereses matemáticos acerca del uso de la perspectiva. Se trata de una noticia según la cual Vicent Mestre compró el 8 de marzo de 1601 en las almonedas de Antoni Real, fallecido catedrático de matemáticas en el Estudi General de Valencia, un libro "intitulat Perspectiva y especularia de Euclides, por Pedro Ambrosio Onderis, en quart, imprés en Madrid, 1589, per quatre sous". Archivo del Reino de Valencia, Valencia (ARV), Protocolos, Joaquín Martí 10.177. La primera edición de este libro fue publicada en Madrid, en casa de la viuda de Alonso Gómez, en 1584. Aunque desconocemos la forma en la cual pudieron concretarse tales conocimientos teóricos sobre perspectiva en sus obras, la importancia de su adquisición debe sopesarse en relación con el contexto artístico y científico de la Valencia del momento.

12 Documentos 18, 19 y 20 del apéndice documental. VILLALMANZO, Jesús, 1997, pp. 81-82.

${ }_{13}$ Villalmanzo interpretó en su análisis documental y corográfico de esta pintura que el último destinatario de esta copia pudo ser el duque de Lerma. VILLALMANZO, Jesús, 1997, p. 60. Sin embargo, en ninguno de los ya publicados inventarios de pinturas del duque hemos podido identificar una obra que responda a esta temática. Sí que encontramos en el inventario de enero de 1628 del palacio ducal de Lerma, realizado por orden del nieto del duque cuando este último ya había fallecido, un lienzo "de dos varas de alto y bara y media de ancho poco más o menos que está pintada la toma de los moriscos de la sierra de Valencia sin marco, y está en el passadiço de la plaça donde el despeñadero". Archivo Ducal de Medinaceli, Toledo (ADM), Dénia-Lerma, leg. 54, n. 3, f. 4v. Es decir, posiblemente una versión de uno de los cuadros de las rebeliones de los moriscos en las sierras de Cortes y Laguar. Véase GIL SAURA, Yolanda, 2018, p. 144. Sarah Schroth ya se había referido a este inventario y a la pintura en cuestión en su estudio sobre la colección pictórica del duque de Lerma. SCHROTH, Sarah, 1990, pp. 89-90. Cabe señalar, por último, que junto a este cuadro, en el inventario de 1628 se referenciaron dos mapas en mal estado de la ciudad de Valencia y Dénia y un lienzo que tampoco era de servicio nuevamente del estado de Dénia. ADM, Dénia-Lerma, leg. 54, n. 3, ff. 4r-4v. 


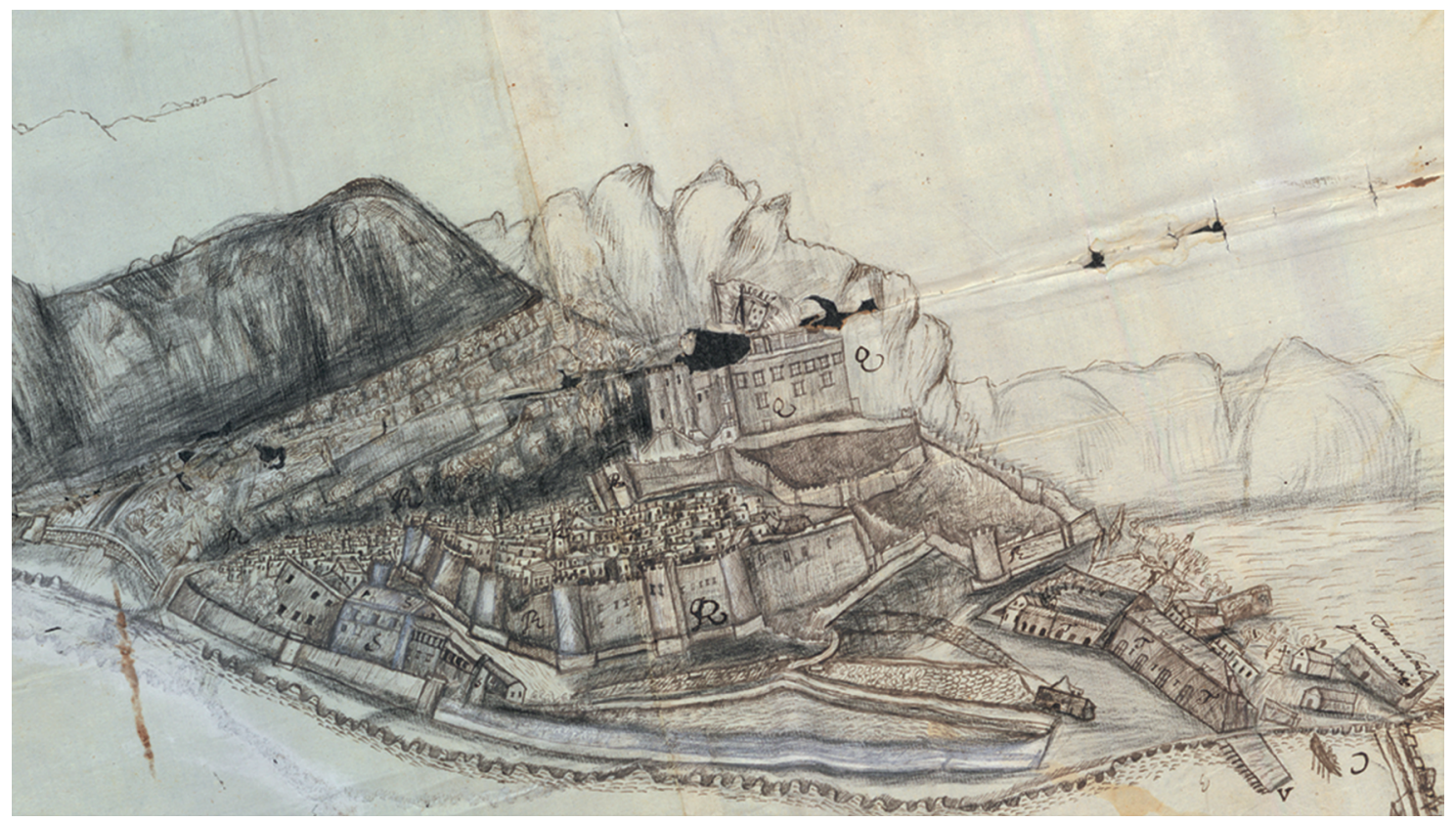

Fig. 3. Planta de Dénia y su puerto y castillo, finales del siglo XVII. Archivo Ducal de Medinaceli, Archivo Histórico, leg. 267, ramo 6.

Sea como fuere, como ya se ha sugerido, Mestre tuvo muy seguramente acceso directo a la contemplación de la ciudad de Dénia, garantizándose así que la representación del municipio fuese un testimonio de primera mano y basado en su propia experiencia. Entre 1612 y 1613 el palacio del duque de Lerma estaba en proceso de transformación, y como puede verse en la pintura, ya se habían levantado los cuartos reales a los que hacía referencia Cabrera de Córdoba en diciembre de $1611 .{ }^{14}$ Años después, y sobre todo entre 1616 y 1618, las obras se aceleraron para acoger a Felipe III y la familia real en el contexto de la celebración de Cortes en la ciudad de Dénia, las cuales nunca llegarían a efectuarse por la caída en desgracia del duque de Lerma. Además, la representación de los porches con tejaroz en el frente meridional del palacio, donde entonces se guardaba la artillería, certifica que todavía en aquel momento no se había construido la escalera que permitía la entrada a la residencia, erigida como después veremos en varias fases.

Con todo, pese a que la pintura de Mestre es una crónica visual de gran valor documental, su cierto grado de idealización en algunos detalles arquitectónicos condiciona su lectura como fuente totalmente fiable. En este sentido, la vista inédita de la ciudad de Dénia que damos a conocer (Fig. 3), de mayor veracidad formal, permite contrarrestar tales carencias y examinar la evolución arquitectónica del edificio hasta la muerte del duque de Lerma, su mayor promotor. La vista en cuestión forma parte de un documento del Archivo Ducal de Medinaceli de Toledo llamado Planta de Dénia y su puerto y castillo y un memorial dado al señor duque de Lerma representándole lo que importava componer dicho puerto..$^{15}$ En esta instancia remitida al duque de Lerma se le informaba de las

${ }^{14}$ En su estudio sobre la pintura de Mestre, Villalmanzo aseguró que las reformas que aparecen reflejadas en el palacio del duque de Lerma fueron llevadas a cabo con motivo de la estancia de Felipe III en Dénia en 1599. Sin embargo, como ya hemos apuntado, las intervenciones fueron posteriores a esta fecha. VILLALMANZO, Jesús, 1997, p. 58.

15 ADM, Archivo Histórico, leg. 267, ramo 6. La vista inédita que aportamos forma parte de un documento de mayor tamaño con ulteriores representaciones de esta zona costera. La unidad documental completa presenta una leyenda con la identificación de los diferentes elementos de interés figurados. El Archivo Ducal de Medinaceli conserva otros mapas de la ciudad de Dénia, aunque de menor interés por lo que atañe a la representación del castillo y palacio. Del siglo XVIII son seguramente los mapas con la siguiente signatura: ADM, Archivo Histórico, leg. 267, ramos 5 y 7. En este último también se encuentra representada la población del Vergel. Otro interesante mapa de Dénia puede ser consultado en ADM, Mapas y planos, n. 43. 


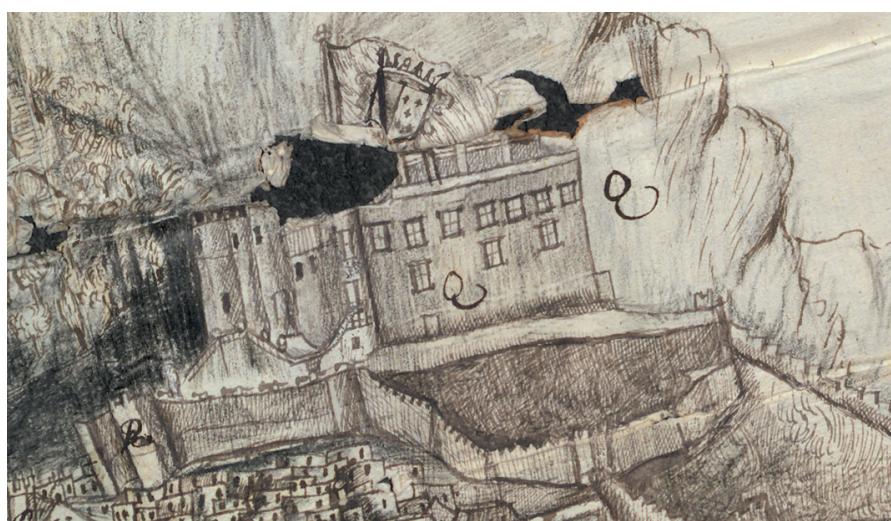

Fig. 4. Planta de Dénia y su puerto y castillo. Detalle.

actuaciones urgentes y necesarias que se tenían que llevar a cabo para la conservación del puerto de Dénia. Básicamente se sugería la limpieza del fondeadero si no se quería que en un futuro éste terminase por cegarse y cerrarse, lo cual ocasionaría la inversión de grandes sumas de dinero. Como se indica en dicho memorial, las dificultades que tenían las embarcaciones para fondear en el puerto de Dénia fueron una constante a lo largo del siglo XVII. El último de los episodios que se enumeran para explicar dicha incomodidad a la hora de atracar es de agosto de 1672, cuando la escuadra de las siete galeras de España lo pudo conseguir solo con gran esfuerzo. Por consiguiente, tanto el documento como la adjunta vista de Dénia deben de ser posteriores a tal suceso histórico, seguramente de finales del siglo XVII. La relevancia de esta imagen de Dénia y de su castillo y palacio (Fig. 4) radica en el hecho de ser, hasta el momento, la fuente visual más cercana en el tiempo a la muerte del duque de Lerma, revelándose por ende como un testimonio de primera mano para solo conocer con detalle su legado constructivo en la ciudad cabeza de sus estados valencianos. De nuevo, como en las dos anteriores ilustraciones, el punto de vista adoptado permite la contemplación de la ciudad desde el ángulo meridio- nal, saliendo a la luz una vez más los flancos sur y este de la fortaleza. En lo que se refiere al palacio, se observa ya la escalera monumental de triple tramo que daba acceso al mismo, con sus cubos con ventanas y balcones y el ala oriental de tres pisos con tres ventanas en el primer nivel, siete en el segundo y el antepecho de piedra de la terraza con cuatro bolas de raíz clasicista en sus esquinas. En lo alto, como también puede verse en el cuadro de Mestre, ondeaba el estandarte con el escudo de armas de los Sandoval y Rojas.

Ya del siglo XVIII es la imagen del castillo de Dénia de Sebastián Caballero del Archivo General de Simancas (1715), de gran interés para examinar el estado del palacio del duque de Lerma en su lienzo septentrional (Fig. 5), donde en época de Felipe III se concibieron y adecentaron los huertos personales del monarca y su privado y donde también se encontraba la dehesa, una tierra acotada y destinada al desarrollo de actividades cinegéticas. Como apunta Ivars, es posible que esta datación sea errónea, pues la imagen de la residencia que se muestra es anterior a la Guerra de Sucesión, cuando fue "intensamente bombardeado y prácticamente derrocado". ${ }^{16}$ Posteriores fuentes visuales de relevancia histórica para conocer el devenir del palacio son, por ejemplo, la pintura de la costa de Dénia de Mariano Sánchez de finales del siglo XVIII y el grabado y dibujo original Vue de Denia de A. de Laborde de inicios del siglo XIX, publicado en su monumental Voyage pittoresque et historique de l'Espagne (1808-1820). ${ }^{17}$ Finalmente, la imagen actual del palacio (Fig. 6) dista mucho del estado que presentaba en la época de su mayor esplendor, durante el gobierno de Lerma. El núcleo principal fue totalmente derrocado a principios del siglo XVIII, mientras que en el ala este, actual Museo Arqueológico de Dénia, la pérdida posterior del piso superior y su terraza acabó por desvirtuar una construcción que solo con actuaciones recientes ha recuperado parte del lustre original. Nos referimos a la restauración de los espacios del actual museo, la recuperación de la escalera monumental, la rehabilitación de la plataforma del castillo con

Por último, en una publicación reciente se han examinado dos nuevos documentos cartográficos de esta ciudad en dicho archivo, un mapa del siglo XVIII con los términos de Xàbia, Gata y Teulada, limítrofes con el de Dénia, y un plano de una dársena para el puerto de Dénia de 1606. SÁNCHEZ GONZÁLEZ, Antonio, 2017, pp. 242-244.

16 IVARS, Josep, 2015, p. 200.

17 La vista de Dénia del pintor valenciano Mariano Sánchez formaba parte de la serie Vistas de puertos que Carlos III le encargó en 1781. RUíz ALCÓN, María Teresa, 1976, pp. 18-24. El lienzo fue reproducido y comentado en IVARS, Josep, 2015, p. 72. Sobre el grabado y dibujo original del castillo de Dénia en la obra de A. de Laborde y su importancia histórica para conocer la desaparecida estatua marmórea del duque de Lerma, véase CAMPOS-PERALES, Àngel, 2018a, p. 400 y ss. Hasta el momento la mejor recopilación de imágenes del castillo de Dénia es la obra de Ivars, consultable en IVARS, Josep, 2015. 
su nuevo enlosado y las más actuales intervenciones arqueológicas llevadas a cabo en el Palau Vell, es decir, el corazón del palacio medieval.

\section{El proceso de transformación del palacio y su entorno urbano. El duque de Lerma, Felipe III y la frustrada visita real a Dénia para la celebración de Cortes}

Como informaba Cabrera de Córdoba a finales de 1611, Felipe III estaba deseando volver a Dénia para ver los dos cuartos reales que el duque de Lerma había levantado en el castillo de Dénia. Aunque no hemos encontrado documentación relativa a esta inicial fase constructiva, sí que podemos constatar en las fuentes visuales coetáneas, como la pintura de la expulsión de los moriscos de Vicent Mestre, que la alteración arquitectónica del viejo palacio estaba bastante avanzada. De este modo, conociendo la explícita pretensión del monarca de volver a visitar Dénia, que se remontaba al menos hasta meses antes de 1612, podemos ahora poner en contexto un conjunto de noticias que cobran un claro sentido histórico. En el marco de estos anhelos de Felipe III de retornar a tierras valencianas se sitúa no solamente el embellecimiento del palacio Dénia, sino también, por ejemplo, la incorporación al castillo de esta ciudad de la estatua marmórea del duque de Lerma -contratada el 28 de agosto de 1612 y embarcada en Génova el 9 de agosto de 1613- así como la compra a expensas del mismo Lerma de la Casa de la Huerta, sus jardines, búcaros, porcelanas y vidrios que había poseído el Patriarca Juan de Ribera en Valencia, certificada el 13 de mayo de 1613. ${ }^{18}$ Con estas acciones el duque buscaba disponer de unos espacios cortesanos con los que servir, agradar y entretener al rey y a su familia, concibiéndolos como una suerte de "reales sitios" que se incluirían en la agenda valenciana de Felipe III. ${ }^{19}$

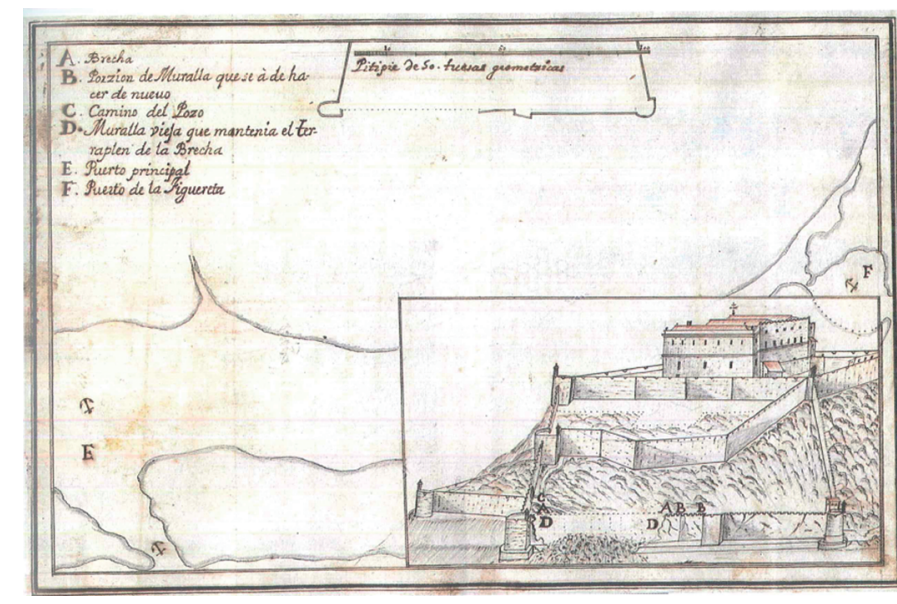

Fig. 5. Castillo de Dénia, 1715. Archivo General de Simancas, MPD, 26, 110.

La primeras noticias que conocemos del proceso de acondicionamiento del palacio desde el testimonio de Cabrera de Córdoba son del 18 de octubre de 1615, cuando Pedro Martínez, albañil de Dénia, se documenta por primera vez realizando ciertos "reparos" en esta residencia, ${ }^{20}$ aunque se tratan siempre de trabajos menores. Desde esta fecha y hasta finales de 1616 encontramos a diferentes profesionales, como el mismo Martínez, los carpinteros Onofre Palmir y Onofre Ramón, el cerrajero Rafel Martí, el albañil José Segara y el herrero Vicente Gavardó percibiendo dinero por sus labores en el castillo y por cuenta del duque de Lerma, cuya hacienda en el estado de Dénia era administrada por Manuel González de Andrada. Posiblemente una de las obras de mayor relevancia de cuantas se llevaron a cabo durante estos meses fue el aderezo de "la tribuna y puente" de la iglesia mayor de Dénia, una especie de pasadizo de madera ya construido que conectaría la cercana iglesia parroquial con el palacio. ${ }^{21}$

\footnotetext{
18 Sobre la escultura, véase CAMPOS-PERALES, Àngel, 2018a, pp. 395-410. Sobre la compra de la Casa de la Huerta que había pertenecido al Patriarca Juan de Ribera: CAMPOS-PERALES, Àngel, 2018b, pp. 309-327.

19 Bernardo J. García García ha estudiado este fenómeno, sobre todo centrándose en el ámbito castellano, en: GARCíA GARCíA, Bernardo J., 2016, pp. 393-440. Además, muchas de las claves para entender la actividad constructiva y artística de Lerma en Dénia pueden encontrarse en otros estudios que han analizado el gusto artístico de la época durante unos años en los que el duque fue un agente trascendental en la configuración de los espacios cortesanos. De esta forma, véanse los capítulos sobre "Los gustos pictóricos en la Corte de Felipe III" y "Felipe III y las artes" en la fundamental obra de Miguel Morán y Javier Portús. MORÁN, Miguel; PORTÚS, Javier, 1997, pp. 13-29 y 63-82.

20 Archivo del Real Colegio Seminario de Corpus Christi de Valencia, Valencia (ACCV), Protocolos, Francesc Dionís Cercós 20.767. Para los trabajos de 1615 véase el protocolo citado, mientras que para las labores de 1616 véase: ACCV, Protocolos, Francesc Dionís Cercós 20.768.

21 Pago de 92 reales castellanos al carpintero de Dénia Onofre Ramón el día 27 de mayo de 1616: "venyte y sinco reales por sinco días se a ocupado en aderesar la tribuna y puente para pasar a daquella de la yglesia mayor, a razón de sinco reales el día, venyte y tres reales de manos de hazer". ACCV, Protocolos, Francesc Dionís Cercós 20.768.
} 


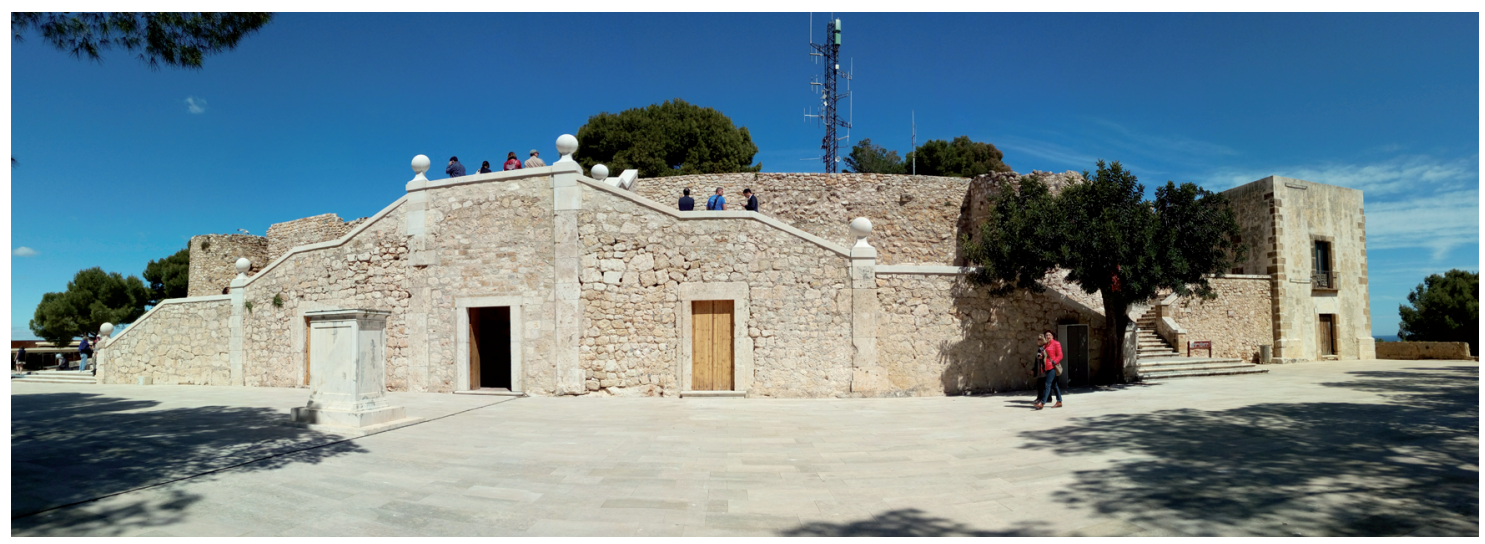

Fig. 6. Estado actual del palacio del castillo de Dénia. Fotografía del autor.

No obstante, las actuaciones promovidas por Lerma en el castillo de Dénia no se intensificaron hasta finales del mencionado año de 1616, coincidiendo con el inicio de la utilización de las finanzas reales para sufragar tales gastos. El origen de esta campaña constructiva y de acondicionamiento del palacio, que se prolongó en el tiempo hasta finales de 1618 , lo encontramos en una carta del 20 de septiembre de 1616 remitida por el duque de Lerma a Gómez Suárez de Figueroa, duque de Feria y virrey de Valencia por aquel entonces, en la cual se le informaba de lo siguiente:

Juan de Chavarria, a cuyo cargo a estado la obra del castillo de Dénia, va a ver y adrezar el apossento para su magestad y para los príncipes nuestros señores y señora infanta María conforme a las trazas y relación que para ello lleva, para cuyo effecto manda su magestad que V.e ordene se le dé el dinero necesario y todo el favor y aiuda y recaudos para ello, embiando persona a quien Chavarria acuda con lo que huviere menester assí para esto como para la obra que se huviere de hazer allí para el servicio de su magestad y altezas, y que esto ssea sin perder una hora de tiempo en ello porque esté todo el aposento acomodado para su llegada. [...] $]^{22}$
La misiva merece una atención especial por varias razones. Por una parte, en ella se certificaba que Juan de Chavarria sería el maestro de obras a cuyo cargo estarían las actuaciones que se realizasen en el castillo de Dénia. Sobre el mencionado Chavarria sabemos poco, aunque lo suficiente como para advertir que provenía del ámbito castellano, seguramente del círculo de Fray Alberto de la Madre de Dios, a tenor de la documentación publicada. ${ }^{23}$ Asimismo, los evidentes paralelismos formales entre las obras de Lerma y Dénia se explican porque, en efecto, Chavarria viajó desde la Corte hasta esta ciudad valenciana con unas trazas y relaciones predeterminadas para ejecutar los aderezos necesarios en el aposento "para su magestad y para los príncipes nuestros señores y señora infanta María". Una vez en Dénia, Chavarria fue atendido inmediatamente por personas entendidas en la materia de trazas y obras, como eran el noble Pere Joan de Vilanova y el carpintero de las obras reales del Reino de Valencia Vicent Mabres. ${ }^{24}$

Por otra parte, como también se apunta en la carta, las obras serían materializadas a expensas del

${ }^{22}$ ARV, Batllia, lib. 297, f. 458r. La carta se encuentra reproducida en el día 8 de octubre de 1616 de la sección Deliberacions Patrimonials, cuando se informa de las intenciones del duque de Lerma. No obstante, a la espera de una orden real firmada por el mismo monarca, que finalmente es despachada en Madrid a 20 de octubre de 1616, se decide solamente empezar a trabajar la madera en el modo solicitado por Chavarria y que ciertas personas entendidas en la materia de trazas y obras, como eran Pere Joan de Vilanova "cavaller" y Vicent Mabres "fuster de les obres reals", fueran a Dénia para citarse con dicho Chavarria. La memoria de la madera y clavos que requiere Chavarria puede consultarse en: ARV, Batllia, lib. 297, ff. 454r-455r. El 10 de noviembre de 1616 se decreta que se envíen las primeras mil libras del patrimonio real para las obras de Dénia, cuando ya ha sido despachada la orden del rey. ARV, Batllia, lib. 297, f. 465r.

${ }^{23}$ Véase BUSTAMANTE GARCíA, Agustín, 1975, pp. 369-388, donde se documenta a Juan de Chavarria, maestro de obras vecino de Madrid, en las labores de albañilería del Real Convento de la Encarnación de Madrid entre 1611 y 1613. Debo esta información a la generosidad del Dr. José Miguel Muñoz Jiménez. También sabemos que Chavarria procedía del medio castellano por una carta de poder del 10 de junio de 1617 que otorgó en Dénia al también maestro de obras Juan de Orosa, residente en Madrid, para vender ciertas casas que el primero tenía en la villa de Madrid. ACCV, Protocolos, Francesc Dionís Cercós 20.769.

24 Véase la nota 22 
patrimonio real, siendo enviadas las primeras mil libras valencianas el 10 de noviembre de 1616, cuando ya había sido despachada en Madrid la orden real firmada personalmente por el monarca. ${ }^{25}$ Como seguidamente veremos, los pagos por las obras de esta intensa campaña constructiva pueden fecharse entre el 23 de octubre de 1616 y el 8 de agosto de 1618 y se encuentran perfectamente recogidos entre cuatro fuentes documentales: los protocolos del notario Francesc Dionís Cercós y las secciones del Archivo del Reino de Valencia Mestre Racional y Batllia -Àpoques y Deliberacions Patrimonials-. ${ }^{26}$ Además, que Lerma se caracterizase por confundir las finanzas públicas con las propias es algo que se ha puesto repetidamente de manifiesto. Seguramente la razón que pueda explicar la utilización de la hacienda real para reformar su propio palacio privado se encuentre en el motivo de la frustrada visita real: la celebración de Cortes del Reino de Valencia en la ciudad de Dénia. ${ }^{27}$

¿Cómo cristalizaron tales desembolsos en el castillo y palacio del duque de Lerma en Dénia? Es complicado determinar hasta qué punto la empresa constructiva de 1616-1618 pudo completar el acondicionamiento de unos cuartos reales que ya habían sido levantados antes de 1612, pues como ya hemos visto en el cuadro de Vicente Mestre, el ala oriental de palacio estaba muy avanzada entre 1612 y 1613 . Es más, los pagos son normalmente escuetos en lo que respecta al espacio de actuación, siendo una excepción el caso de la construcción de las cocheras y carroceras del rey en el barrio portuario de Dénia, como veremos. Sin embargo, las grandes cantidades de dinero desembolsadas semanalmente durante estos dos años y la contratación de un notable grupo de profesionales, entre canteros, albañiles, peones, carpinteros, cerrajeros, herreros, jardineros etc., ponen de relieve que se estaba ante una campaña constructiva de gran envergadura. $^{28}$

Así, uno de los primeros ámbitos de actuación fue la zona costera, donde se reconstruyó el puente de madera que a manera de muelle facilitaba el embarque y desembarque de personas y mercancías, presente en la cartografía histórica desde el plano de 1575 (Fig. 1). Para tal cometido, el 3 de diciembre de 1616 se compraron las primeras tablas, Ilegadas desde Vinaròs, ${ }^{29}$ más tarde estacas de pino y posteriormente unas tablas llamadas "anguiles". ${ }^{30}$ El puente fue terminado antes del 27 de mayo de 1617, cuando se pagaron a Miguel Verí, mallorquín, ulteriores tablas de madera. ${ }^{31} \mathrm{En}$ este mismo barrio portuario, a escasa distancia del muelle, se levantaron las cocheras y carroceras del rey, destinadas a albergar los coches, caballos y acémilas del monarca. La primera noticia conocida de su génesis es del 11 de febrero de 1617, cuando se fecha una memoria de la madera necesaria

\footnotetext{
25 Véase la nota 22.

${ }^{26}$ La sección en la que más profusamente enumeran estos pagos los funcionarios reales encargados de administrar el patrimonio real en el Reino de Valencia es la de Mestre Racional, y a ella nos remitiremos con frecuencia en nuestro estudio. Véase: ARV, Mestre Racional, n. 11.647 y n. 11.648.

27 "Ha de venir sa magestat per a celebrar Corts al present Regne en la ciutat de Dénia, y a la instància que.s fa per part del dit Chavarria per a què se li done tot lo sobredit que diu ser necessari per a fer lo dit aposento seria danyosa y culpable la dilació [...]". ARV, Batllia, lib. 297, f. 458v. La decisión de convocar Cortes en Dénia estaría ya tomada a finales de julio de 1616, pues del 29 de este mismo mes es un memorial reproducido en las Actas del Consell de Dénia según el cual este ente municipal había de tomar una serie de medidas para recibir a Felipe III durante el mes de agosto de 1616. Archivo Municipal de Dénia, Dénia (AMD), Llibre de Consells 1613-1622, ff. 61v-64r. Dicho documento está reproducido en las deliberaciones del día 25 de septiembre de 1616.
}

28 Las cuantías semanales de libras valencianas que se desembolsan y la relación de profesionales contratados pueden consultarse en: ARV, Mestre Racional, n. 11.648. Para que nos hagamos una idea, se enviaron a Dénia 1.000 libras valencianas del patrimonio real el 10 de noviembre de 1616, el 9 de diciembre de 1616, el 5 de enero de 1617 y el 16 de febrero de 1617; 2.000 libras más el 9 de marzo de 1617; 2.000 libras el 8 de abril de 1617; 1.425 libras, 18 sueldos y 5 dineros el 23 de junio de $1617 ; 2.000$ libras el 28 de septiembre de 1617; 2.000 libras el 12 de diciembre de 1617; 1.000 libras el 11 de enero de 1618; 1.300 libras el 15 de febrero de 1618; 1.000 libras el 17 de julio de 1618; y unas últimas 1.008 libras el 17 de octubre de 1618. ARV, Batllia, lib. 297, ff. 465r, 467r, 475r, 509r, 514r, 516r, 525r, 545r, 554v, 557r, 560r, 582r, 594r. Todavía en los años 1620 y 1621 se estaban liquidando deudas por los trabajos realizados en Dénia. Véase ARV, Batllia, lib. 298, ff. 81r y ss.

${ }^{29}$ ARV, Mestre Racional, n. 11.648 , f. 45 r.

${ }^{30}$ ARV, Mestre Racional, n. 11.648, f. 230r y 344v.

${ }^{31}$ ARV, Mestre Racional, n. 11.648, f. 542v. Miguel Verí, agricultor de Sagra, también está documentado en los protocolos notariales, cobrando 50 libras por 200 estacas para el puente el 18 de febrero de 1617 y 71 libras y 12 sueldos por más tablas el 23 de mayo de 1617. ACCV, Protocolos, Francesc Dionís Cercós 20.769. Las tablas más grandes medían 163 palmos, unos 37 metros actuales, la distancia que el puente de madera penetraría en el mar. 
para su construcción. ${ }^{32}$ Sin embargo, no fue hasta el 1 de marzo de ese mismo año cuando se mandó la primera carga de arena desde Xàbia.. ${ }^{33}$ Desde las canteras de esta misma población del marquesado de Dénia llegaron también las piedras requeridas para su edificación, descritas en la documentación como piedras de "fonament", "esquines", "machos" y de "arch". El encargado de proveer y fletar tales sillares fue el maestro picapedrero Juan Minyà, residente en Xàbia, al que se le pagaron en diferentes tandas desde el 22 de abril de 1617 hasta el 14 de enero de 1618 más de un millar de piezas. ${ }^{34}$ No obstante, las actuaciones llevadas a cabo en la cimentación del edificio estuvieron marcadas por varios contratiempos. El inicio de las obras a principios de 1617 provocó las quejas de los propietarios de boticas en la orilla del mar, justo enfrente de la construcción real, que se vieron perjudicados por el agua que se estaba sacando de los cimientos de las cocheras. La solución adoptada por Juan de Chavarria fue construir un muro para desviar este caudal, medida que se sumó a la tomada tiempo después, consistente en la elaboración de una noria para seguir extrayendo agua de aquella zona costera. ${ }^{35}$ Con todo, considerando la información aportada en la documentación, las cocheras del rey fueron seguramente el inmueble que aparece representado junto al puente de madera en la vista de Dénia de finales del siglo XVII (Fig. 3). Parte de esta obra arquitectónica se encuentra actualmente en el Carrer del Pont de Dénia y ha sido redescubierta gracias a las obras que se están ejecutando en este mismo lugar para inaugurar un centro gas- tronómico. ${ }^{36}$ A la espera de futuras investigaciones, cabe apuntar que la importancia de estas arquitecturas, aunque fragmentarias, radica en el hecho de ser un valioso ejemplo del legado patrimonial del duque de Lerma en Dénia durante sus años de acceso al poder, una de las épocas más doradas de la historia de esta ciudad valenciana.

Asimismo, para no ser vistos desde el muelle de madera hasta el acceso al castillo, el rey y su Corte podían atravesar una serie de pasadizos privados, siguiendo la ya conocida costumbre de época de los Austrias que Lerma puso en práctica en sus residencias personales de Lerma y Valladolid. ${ }^{37}$ Conocemos por la documentación de 1616-1618 un primer pasadizo que preservaba el contacto de la Corte con el pueblo desde el puente hasta la base del castillo. ${ }^{38}$ Este primer pasaje conectaría con una escalera cubierta por la que se subía directamente al castillo, seguramente el mismo pasadizo al que hizo referencia Cabrera de Córdoba el 21 de febrero de 1604 cuando Felipe III volvió a visitar Dénia: "Vio S.M. un pasadizo que el Duque había mandado hacer muy largo, para bajar cubierto desde la fortaleza hasta la costa de la mar". ${ }^{39}$ Posiblemente la decisión de erigir estos pasadizos estuvo condicionada por el vergonzante episodio que vivió Felipe III en Dénia en agosto de 1599, cuando después de una larga y calurosa jornada de pesca de atunes en Xàbia el rey cayó enfermo de calentura. Para salvar la enriscada pendiente que daba acceso al palacio lo tuvieron que subir en silla, como nos cuenta nuevamente el cronista real. ${ }^{40}$ Finalmente, como ya hemos visto,

32 ARV, Batllia, lib. 297, f. 504r. Mucha de la madera destinada a las obras de Dénia fue suministrada por Francisco Fernández Cabrera y Bobadilla, marqués de Moya, al cual se le pagaron importantes sumas de dinero por diferentes cargas el 18 de abril de 1617. De este día son tres noticias de la sección de ápocas de Batllia General. Véase ARV, Batllia, lib. 94, ff. 607v-608v.

33 ARV, Mestre Racional, n. 11.648, f. 284r.

${ }^{34}$ ARV, Mestre Racional, n. 11.647, sin foliar. Las cocheras estarían terminadas a finales de enero de 1618, ya que entre el 28 y el 29 de ese mismo mes se estaban pagando las argollas de hierro para las puertas. ARV, Mestre Racional, n. 11.648, f. 954r.

35 La decisión tomada por Chavarria es del 20 de febrero de 1617. ACCV, Protocolos, Francesc Dionís Cercós 20.769. Por otra parte, la construcción de la noria está documentada en: ARV, Mestre Racional, n. 11.648, f. 343r.

${ }^{36}$ Se llegó a esta conclusión después de contrastar la información de archivo con la cartografía histórica y los patentes restos arquitectónicos conservados. Debo a Josep A. Gisbert la noticia del redescubrimiento de estas arcadas, que pudimos identificar como restos de las antiguas cocheras y carroceras después de conocer la documentación de archivo y analizar la cartografía histórica. La noticia ha salido a la luz en medios de comunicación comarcales, como La Marina Plaza, con un artículo digital del 15 de marzo de 2019 llamado "Las obras del centro gastronómico de Baix la Mar sacan a la luz el edificio que construyó Felipe III para sus carruajes reales en Dénia". Véase: <https://lamarinaplaza.com/2019/03/15/las-obras-del-centro-gastronomico-de-baix-la-mar-sacan-a-la-luz-el-edificio-que-construyo-felipe-iii-para-sus-carruajes-reales-en-denia/> (Fecha de consulta: 25-3-2019)

37 CERVERA VERA, Luis, 1967a, pp. 138-143.

38 "Lo pasadís anant del peu del castell al pont". ARV, Mestre Racional, n. 11.648, f. 36r.

39 CABRERA DE CÓRDOBA, Luis, 1857, p. 207. En la campaña constructiva de 1616-1618 se compraron clavos para fijar un cerrojo en "la porta del peu de la scala que baxa del castell al mar per on a de baxar se magestat". ARV, Mestre Racional, n. 11.648, f. 256 r.

40 "Sucedió que aquel día hizo excesivo calor, y como el sol reberberaba en el agua hizo daño a S. M., y así volvió a Dénia con calentura; al cual subieron en silla a la fortaleza donde se han aposentado, porque el sitio es enriscado, y si no es de aquella manera no se puede subir a ella". CABRERA DE CÓRDOBA, Luis, 1857, p. 34. 
un tercer pasadizo conectaría el palacio con la tribuna privada de Lerma en la iglesia parroquial de Dénia. ${ }^{41}$ Por otra parte, las operaciones de carácter urbano no solo mejoraron el aspecto de la ciudad en su litoral. El duque de Lerma ordenó que igualmente se renovase el Portal de la Creu, también conocido como Portal de Terra o de Ondara, la puerta oeste de acceso a la ciudad, por donde Felipe III había de entrar en su llegada a Dénia. La propuesta para el nuevo portal, remitida al Consell de Dénia el 22 de octubre de 1616, se basaba en su ensanchamiento para que pudiesen pasar los carros castellanos, con nuevas puertas, y que se restaurase el lienzo de muralla que se extendía hasta la torre. ${ }^{42}$ Como aseguró Rosa Seser, es probable que el mandato de Lerma llegase a materializarse, pues en 1621 el Consell adquirió un retablo para ser colocado encima del portal, quizás el ornato final de la puerta reformada. ${ }^{43}$

Las tareas de acondicionamiento del periodo 16161618 fueron especialmente intensas en el palacio de Dénia. Frente al lienzo norte de la residencia se adecentaron los jardines privados del duque y el monarca, por lo menos desde el 8 de abril de 1617, cuando llegó al castillo de Dénia el jardinero del palacio Real de Valencia, Juan Salvador Nàjer, para conservar las plantas y hierbas que a partir de entonces se iban a cultivar. Durante las tres primeras semanas de abril se empezó a subir tierra, cañas y agua para los jardines, aunque no fue hasta el 29 de ese mismo mes cuando llegaron las primeras plantas: arrayanes y otras hierbas trasplantadas presumiblemente desde las laderas del cercano Montgó. Más tarde, el 3 de junio de 1617 se hizo relación de las plantas que habían sido traídas en barca para los jardines del castillo, entre las que había cipreses pequeños, mejorana, rosas, albahaca, jazmines, naranjos pequeños, limoneros y poncileros, así como material para preparar su cultivo. ${ }^{44}$ Asimismo, se añadieron el 12 de agosto de ese mismo año 24 tiestos de arrayanes con las armas del duque de Lerma, que habían sido traídos desde Mallorca, aunque esta vez pagados por cuenta del privado, y lirios el 22 y 23 de octubre de $1617 .{ }^{45}$ En fechas posteriores y hasta mediados de 1618 se hicieron obras y se plantaron ulteriores arrayanes y hierbas en los jardines, resultando un rico vergel de árboles frutales, flores y olorosas hierbas entre gruesas paredes con puertas, cuya contemplación se podía efectuar desde los aposentos más personales de la residencia, como la alcoba del duque. ${ }^{46}$

Como ya hemos reiterado, la ampliación oriental del antiguo palacio medieval estaba muy avanzada a finales de 1616, y este hecho se confirma examinando nuevamente la documentación de estos años. Sabemos que la galería del rey, situada justo debajo de la terraza con el antepecho de piedra y el estandarte, estaba edificada a principios de 1617, cuando se abona un anticipo para la elaboración de canales de cobre en la parte superior de este aposento y de la galería del príncipe. ${ }^{47}$

\footnotetext{
${ }^{41}$ Véase la nota 21.

42 "Ha juntat lo dit consell fonch proposat que lo dit Pere Esteve, jurat en cap, que per lo que havem fet ajuntar lo dit Consell és per fer-los a saber que lo governador don Jofré de Blanes ha vengut de la Cort hi.ls havia comunicat la orde que portava del senyor duch que era entre altres coses que per quant sa magestat venint a la dita ciutat de Dénia a tenir Corts havia de entrar per lo Portal de la Creu y lo dit Portal era molt rohín y estret y per aquell no podien entrar carros castellans, que per ço era sa voluntat y encarregava que la ciutat fes un nou portal de pedra picada y portes molt bones y que.s repare tot lo enfront que está devés lo saladar al costat del dit portal, ço és, lo llens fins a la torre, que per ço acorden lo que.ls parega". AMD, Llibre de Consells 1613-1622, ff. 69v-70r. Agradezco a Rosa Seser, archivera municipal, que me señalase la existencia de este documento.

43 SESER, Rosa, 2013, p. 85. Véase: AMD, Albarans de manament 1621, f. 95r. El pago es del 24 de mayo de 1621.

44 "Plantes portades per mar ab barca del patró Batiste Roca per als jardins del castell de Dénia, les quals se són lliurades a Juan Salvador Nàjer, jardiner de dits jardins, les quals a plantades en la present semana en dits jardins". ARV, Mestre Racional, n. 11.648 , f. 563v. Ya el 23 de febrero de 1617 se había expresado la necesidad de enviar cuatro docenas de naranjos y dos docenas de haces de cañas para los jardines. ARV, Batllia, lib. 297, f. 511r. Por otra parte, también en otros documentos se enumeran las plantas compradas para dichos jardines, Ilegadas en su mayoría desde Valencia: ARV, Mestre Racional, n. 11.647, sin foliar.

45 "Pujaren des de la vora de la mar vint y quatre murteres que foren portades de Mallorca a Dénia per compte del duch, posades en sos testos cada una ab les armes del duch en elles, les quals foren pujades en lo castell y posades en los jardins de dit castell". ARV, Mestre Racional, n. 11.648, f. 746r. Para los lirios: ARV, Mestre Racional, n. 11.648, f. 875r. Asimismo, por una noticia del 30 de septiembre de 1617 sabemos que se cultivaron otros jardines en una zona más baja, delante de las oficinas del castillo. ARV, Mestre Racional, n. 11.648, f. 843r.

${ }^{46}$ El 8 y el 9 de octubre de 1617 se habla de subir piedra a los jardines del castillo "per a fer ally parets groses", mientras que el 22 y 23 de octubre se pagan los clavos para la nueva puerta de los jardines. Las gruesas paredes pueden vislumbrarse en la cartografía histórica, por ejemplo en la representación del castillo de 1715 (fig. 5). El 20 y el 21 de mayo de 1618 se estaba subiendo tierra para "lo jardí que està davall lo balcó de la alcoba del duch de Lerma". ARV, Mestre Racional, n. 11.648, ff. 866r, $874 v, 999 r$

${ }^{47}$ Este anticipo es del 18 de febrero de 1617. ARV, Mestre Racional, n. 11.648, f. 231r.
} 
La función de estos canales, que se libran el 22 de julio de 1617, era reforzar la conducción del agua en los conductos de piedra situados encima de la galería del rey y del príncipe y evitar así que los días de fuertes lluvias el agua terminase entrando en el interior del edificio. ${ }^{48}$ Es decir, se trata de un claro ejemplo de la finalidad que tendrán la mayoría de las actuaciones en el palacio durante estos dos años de obras, acondicionar y perfeccionar unos espacios que ya estaban prácticamente acabados. Otras intervenciones de calado fueron, por ejemplo, la instalación de vidrios en ventanas, vidrieras y espejos. Una primera memoria del 14 de enero de 1617 recogía que se requerían 250 vidrios "muy cristalinos" del tamaño de media hoja de papel cada uno, los cuales serían finalmente suministrados un mes después por un tal Antonio Tarrania de la misma ciudad de Dénia. ${ }^{49}$ También en febrero de 1617 se manifestó la necesidad de adquirir "sis mil lladrillos per al sól del quarto de Sa Altesa", 50 posiblemente para algún aposento real que todavía no había sido construido.

En general, gran parte de los trabajos estuvieron destinados a tareas de adecentamiento, como blanquear paredes, colocar cerraduras y bisagras en puertas y ventanas, instalar encerados, rejas, etc. ${ }^{51}$ En particular, merecen una especial atención la contratación de las cerraduras para los aposentos reales, el encargo de los balcones y el empedrado de la plataforma del castillo. Por lo que atañe a la primera de estas actuaciones, el
23 de junio de 1617 se abonaron un total de 152 libras valencianas por 16 cerraduras grandes hechas en Valencia para los cuartos del rey y el duque de Lerma. Cada una de ellas contaba con tres llaves maestras: la primera solo podía dar una vuelta; la segunda, la gran llave dorada, a cuyo cargo tenía el duque de Lerma por ser sumiller de corps, podía dar dos vueltas e inutilizar la primera; la tercera, la del rey, inhabilitaba las dos anteriores. ${ }^{52}$ Más tarde, entre el 17 y el 18 de diciembre de 1617 se compraron nuevamente 16 cerraduras como las anteriores. ${ }^{53}$

En cuanto a los nuevos balcones, encontramos las primeras noticias para su hechura en una memoria del 14 de enero de 1617, cuando desde Dénia se demandaron "sis balcons de ferro conforme a la trasa feta en hun paper en Dénia", ${ }^{44}$ uno de los cuales se ejecutaría por cuenta del duque de Lerma. ${ }^{55}$ El 22 de abril de ese mismo año llegaron desde el Grao de Valencia los dos primeros balcones de hierro "molt grandísims" junto con 6 ménsulas de hierro "grandísimes" para ser acomodados en las ventanas del castillo. Más tarde, el 6 de mayo, se documentan dos nuevos balcones y 6 ménsulas de hierro, mientras que del sexto y último no hemos encontrado noticias. ${ }^{56}$ Los nuevos balcones fueron dorados y guarnecidos con bolas de bronce y se sumaron a los preexistentes, pues como veremos en la última sección de este artículo otros muchos aposentos contaban con estos grandes miradores de hierro. ${ }^{57}$ Podemos hacernos

${ }^{48}$ ARV, Mestre Racional, n. 11.648, f. 698r.

49 En la memoria del 14 de enero se dudaba entre solicitarlos en Cuenca o Barcelona, pues en Valencia no se habían podido encontrar. ARV, Batllia, lib. 297, f. 476r. El 23 de febrero de 1617 se acordaba que fuese Antonio Tarrania el encargado de suministrarlos: "Attès y considerat que per don Joffré de Blanes y Joan de Chavarria se ha escrit a sa excel.lència que Anthonyo Tarrania de la ciutat de Dénia té molts espills crestalins y bons y han embiat la mida de aquells dient són molt a propòsit y que seran menester fins a dos-cents". ARV, Batllia, lib. 297, f. 511r.

50 ARV, Batllia, lib. 297, f. 511 r.

51 Por temas de espacio, hemos preferido eludir la descripción de estos trabajos menores. No obstante, a modo de ejemplo, cabe señalar que el 18 de febrero de 1617 se encomendaba a Damià Túria, pintor de Dénia, la tarea de pintar de verde todas las puertas y ventanas del palacio, cobrando 5 reales castellanos y medio por cada día de trabajo. ACCV, Protocolos, Francesc Dionís Cercós 20.769.

52 "Setze panys grans, que cada pany reb tres claus mestres, ço és, la primera no pot dar més de una volta y la segona de la llave dorada ne dona dos y no pot la primera clau ya obrir, y la tercera que és la que sa magestat que deu guarde té, esta dona tres voltes y no pot entrar dingú de la primera ni segona clau, los quals an servit per als quartos de sa magestat y del duch de Lerma, les quals foren manades fer en València de orde del senyor mestre rational, les quals feren, ço és, Vicent Martí ne feu cinch y Cucarella sis, y Alexos cinch". ARV, Mestre Racional, n. 11.648, f. 623v.

${ }^{53}$ ARV, Mestre Racional, n. 11.648, f. 914v. El encargo fue para el cerrajero de Valencia Bertomeu Cucarella.

${ }^{54}$ ARV, Batllia, lib. 297, f. 476r.

55 El balcón abonado por el duque de Lerma era para la ventana del cubo de su cuarto y fue realizado por los herreros Vicente Gavardó y Matías Puig. El 12 de marzo de 1617 estos dos herreros también cobraron por 16 "balaustres de yerro para las ventanas del oratorio de su excelencia". ACCV, Protocolos, Francesc Dionís Cercós 20.769.

${ }^{56}$ ARV, Mestre Racional, n. 11.648, ff. 457r, 489v.

${ }^{57}$ El pago por las bolas de bronce está registrado en los días 14 y 15 de enero 1618 . Se compraron 14 bolas y se pusieron un par en cada balcón. ARV, Mestre Racional, n. 11.648, f. 948r. Por otra parte, entre el 4 y el 5 de marzo de 1618 se estaba comprando cáñamo para "amantelar la gàbia gran en què lo pintor daurava los balcons". ARV, Mestre Racional, n. 11.648, f. 969v. 
una idea aproximada del resultado final de su colocación a través del grabado de $\mathrm{A}$. de Laborde de inicios del siglo XIX, donde se distinguen claramente los balcones de la ampliación oriental que miraban al mediodía. Lamentablemente no se han conservado, ya que como señaló mosén Francisco Palau Diego en su dietario de Dénia, en el marco de las obras en el castillo por la Guerra de Independencia Española, el 1809 "se bajaron los balcones del palacio del castillo para hierros de las carretas". 58

Por último, las labores en la plataforma del castillo estuvieron dedicadas a obras de empedramiento, sobre todo en la zona norte y hasta la puerta de los jardines, donde estaban las oficinas y la cisterna. ${ }^{59}$ También se construyó un edificio detrás "de las casas de los soldados", ${ }^{60}$ seguramente para el servicio del duque y la Corte, aunque la mayor parte de las tejas, ladrillos, sillares, madera y otros materiales de construcción empleados debieron de estar destinados a la obra de las cocheras y carroceras y al embellecimiento del palacio. El resultado final lo podemos intuir a través de representaciones del castillo posteriores a estos años de trabajos, como la vista de Dénia inédita a la que hemos hecho referencia (Fig. 3). Sin embargo, existieron imágenes del castillo coetáneas a las obras del periodo 1616-1618. Así lo atestigua un documento del 9 de febrero de 1618, cuando se informa de la solicitud que había hecho el duque de Lerma a Juan de Chavarria de componer "modelos de totes les plantes de la sobredita obra estava feta fins al present dia" porque el rey Felipe III quería ver personalmente el progreso de la empresa que se estaba sufragando con el propio patrimonio real. Se estaba cerrando así un círculo que había empezado con las trazas que el mismo Chavarria había llevado desde la Corte hasta Dénia:
En raó d'haver manat lo senyor duc de Lerma a Juan de Chavarria, mestre major de les obres del castell de Dénia i carrosseres $i$ cotxeres de la platja del pont de Dénia que fan per compte de Sa Magestat, en que promptament fes modelos de totes les plantes de la sobredita obra estava feta fins al present dia, en quin punt estaven per Sa Magestat les volia veure, per la qual raó ha convingut a dit Chavarria fer moltes plantes, les quals esperava un propri en València, que venia remès per lo duc de Lerma al governador de Dénia, per a què les remetès promptament, les quals estigueren a punt per dit Chavarria a dos dies del present mes de febrer per a poder-les enugar a València al dit governador de Dénia. [.... ${ }^{61}$

A partir del 1 de junio de 1618 el duque de Lerma se hizo cargo de los pagos por las obras en el casti1 o de Dénia. ${ }^{62}$ Con la caída en desgracia del privado de Felipe III quedaba también malograda la deseada visita del monarca a Dénia para la celebración de Cortes. No obstante, el proceso de transformación del palacio prosiguió y culminó simbólicamente con la terminación de la monumental escalera de triple tramo, que daba acceso al mismo y que encubría parcialmente la vista de su vetusto frente sur. De este modo, el 21 de enero de 1619 se redactaron las capitulaciones para su edificación final. Las obras quedaron a cargo de Sebastián de Javaria -probablemente un hermano de Juan de Chavarria, que ya había trabajado en las obras del castillo-, ${ }^{63}$ quien se comprometía a terminar en el plazo de dos meses y por 200 libras valencianas "las escaleras del castillo de la ciudad de Dénia, que son la principal y del príncipe". ${ }^{64}$ En efecto, la primera de las cláusulas del contrato determinaba que debía acabar la escalera del príncipe, situada en la entrada del palacio, en su interior, con 14 escalones que permitían subir al cuarto del príncipe y articular las dos alturas de la residencia. ${ }^{65}$ La segunda de

58 PALAU DIEGO, Francisco, 1983, p. 131. Sobre los balcones, Baltasar Venero diría en 1776: "[En el palacio] subsisten las salas prinzipales enteras, aunque maltratadas, y sólo el balconaje (de cuios yerros existe más de la mitad, fabricados al maior primor y último coste que cabe en su materia) evidenzia haver sido siempre fábrica de todo esmero". ADM, Dénia-Lerma, leg. 21, n. 2, sin foliar.

59 Véanse los pagos de noviembre de 1617 en: ARV, Mestre Racional, n. 11.648, ff. 884r, 890r.

${ }^{60}$ ARV, Mestre Racional, n. 11.648, f. 906r.

61 ARV, Mestre Racional, n. 11.647, sin foliar.

62 ARV, Mestre Racional, n. 11.648, f. 1.003r. Sin embargo, según otro documento, el duque de Lerma comenzó a pagar las obras del castillo el 1 de julio de 1618 después de entregar 66.000 reales castellanos para tal efecto. La noticia es del 15 de enero de 1619 y puede consultarse en: ACCV, Protocolos, Francesc Dionís Cercós 20.771.

${ }^{63}$ Está registrado entre los canteros que trabajan en las obras de Dénia desde principios de julio de 1617. ARV, Mestre Racional, n. 11.648 , f. $643 \mathrm{v}$.

${ }^{64}$ ACCV, Protocolos, Francesc Dionís Cercós 20.771.

65 "Primeramente e de acabar la escalera del príncipe en donde es la entrada, que son catorze escalones, asy parte de la piedra libra y si faltare la haya de sacar a su costa". ACCV, Protocolos, Francesc Dionís Cercós 20.771. Como veremos en el último epígrafe de este trabajo, la escalera estaba precedida por un aposento de paso de unos 7 metros de largo, 2 de ancho y casi 4 de alto. 
las disposiciones estaba dedicada a la escalera principal, que ya estaba prácticamente terminada, y en la cual tenía que asentar la baranda de piedra con sus bolas por remate y enlosar el último tramo. ${ }^{66}$ Las tres restantes establecían que se habían de terminar las obras en un plazo de dos meses, que los pagos se realizarían en tres asignaciones y que se le darían todos los instrumentos necesarios a excepción de la piedra para la escalera principal, que iría a su costa. ${ }^{67}$

Como maestro de obras y cantero, Sebastián de Javaria coordinaría la construcción material de la escalera principal, aunque muy seguramente el autor de las trazas originales fue otro. Quizás Sebastià Jover, maestro de obras del rey en el Reino de Valencia entre 1598 y 1622, ${ }^{68}$ quien firmó en algún momento de este periodo un memorial de obras necesarias en el castillo de Dénia, entre las que estaba erigir el tramo de escalera que miraba al mar. Es decir, la escalera principal fue erigida en al menos tres fases: la última, de 1619, la acabamos de ver; la segunda, de fecha indeterminada, consistió en la edificación del ramal este de la escalera, para lo cual era imprescindible pasar el porche que cubría la artillería al frente norte del castillo, allanar la roca madre y labrar la piedra y construir los muros de mampostería conforme a la escalera ya existente; ${ }^{69}$ durante la primera, que no sabemos cuándo comenzó, se debió de levantar el primer tiro de la escalera, el que miraba a oeste. A tenor de la documentación consultada, las labores de acondicionamiento del palacio minoraron a partir de 1619 y hasta la muerte del duque de Lerma en 1625 , dedicadas en exclusiva a aderezos menores.

\section{Bienes y aposentos del palacio del duque de Lerma en Dénia}

¿Qué espacios articulaban la residencia privada del duque de Lerma en Dénia? ¿Cuáles fueron los ajuares domésticos que se custodiaban en su interior y cómo se exhibían? Como ya advertimos en un reciente trabajo, ${ }^{70}$ la organización de los aposentos ducales y reales en el palacio de Dénia es una cuestión que siempre había sido desatendida por la historiografía, tanto local como nacional. Sin embargo, como consecutivamente pusimos de relieve, el hallazgo de un documento de 1647, descrito con el título de Relazión de lo que valían las obras y demás vienes que están en el estado de Dénia echas por el señor Duque Cardenal y otra memoria de las mejoras que hizo dicho señor en este estado, permitía paliar tal vacío historiográfico y conocer el estado pormenorizado -habitación por habitaciónde cada uno de los aposentos que estructuraban la construcción con sus dimensiones detalladas en palmos valencianos, así como el conjunto de bienes que había en su interior y exterior en aquel momento. ${ }^{71}$ La relevancia de esta fuente reside en el hecho de ser, hasta el momento, la más completa descripción del palacio poco tiempo después del gobierno del duque de Lerma en Dénia.

En concreto, se inauguraba dicha enumeración de espacios y su tasación en libras valencianas con aquellos edificios y mejoras de la plataforma del castillo de Dénia que rodeaban el palacio, tales como el enlosado y empedrado, el cuarto del alcaide, las oficinas, la escalera principal, "de piedra fuerte con unas bolas por remate", y las caballerizas integradas bajo sus dos vertientes. ${ }^{72}$ Ya en el interior

66 "Ittem que en la escalerra principal se ha de hacentar la baranda y loçar la húltima messa y labrar para esto toda la piedra que falta hasta dexarla en perfiçión con su bola endresada, para lo qual ansimismo ha de sacar a su costa la piedra que faltare". ACCV, Protocolos, Francesc Dionís Cercós 20.771.

67 El 4 de marzo de 1619 se le pagaron a Pere Puig, lapisida de Dénia, 1.922 reales castellanos de los 3.922 totales por "duscientas y sesenta una vara y media de piedra que a cortado en el castillo de Dénia para la frábrica de las escaleras". ACCV, Protocolos, Francesc Dionís Cercós 20.771.

68 ARCINIEGA GARCÍA, Luis, 2009, p. 114.

69 "Primero se ha de quitar la porchada que cubre la artillería y pasarla a la parte de tremuntana entre la cisterna y las casas de los soldados, porque donde está hoy afea mucho el baluarte, y para averse de hazer la escalera para subir al castillo conforme la que está echa, que mire a la parte de la mar, no se puede hazer que no se quite dicha porchada, el gasto que hará de quitarla de allí y pasarla a la otra parte y bolvello a hazer con el mesmo pertrecho será ciento y cincuenta libras, poco más o poco menos"; "segundo, para hazer el ramo de la escalera conforme está el otro de piedra labrada, con todos los fundamentos y paredes de mampostería, con su pasamán de piedra con sus resaltos, con sus bolas y baças, y tachoynada de piedras negras conforme está lo demás, y allanar la peña todo lo que fuere menester para hazer dicha escalera, costará de pertrecho y manos ducientas libras". ADM, Dénia-Lerma, leg. 17, n. 21. Otras de las proposiciones de Jover se correspondían con obras en la entrada del palacio, el aljibe y uno de los patios pequeños de la residencia.

70 CAMPOS-PERALES, Àngel, 2018a, p. 398.

71 En la investigación de 2018 no pudimos abordar el análisis del documento en cuestión debido a la limitada extensión de la misma. Sobre el origen de esta relación de bienes y mejoras del duque de Lerma en el marquesado de Dénia, mandada redactar por Mariana de Sandoval, III duquesa de Lerma, véanse las pp. 396 y ss. La signatura del documento es la siguiente: ADM, Dénia-Lerma, leg. 18, n. 4.

72 ADM, Dénia-Lerma, leg. 18, n. 4, ff. 1v-2v. 
del palacio, los escribanos se ocuparon de describir en primer lugar el cuarto del príncipe, que se levantaba sobre un aposento excavado en la roca madre de 25 metros y medio de largo y 4 y medio de ancho, usado entonces como almacén. ${ }^{73} \mathrm{Al}$ cuarto del príncipe se accedía a través de la escalera terminada en 1619 y estaba configurado por una primera entrada, la primera cuadra, la sala principal, la alcoba, que estaba labrada en la roca, y una ulterior recámara. Todos estos espacios disponían de ventanas y balcones con vistas a los jardines e incluso contaban con un huerto particular al cual se ingresaba a través de una puerta en la recámara.

El aposento de mayor representatividad y suntuosidad en el núcleo antiguo del palacio fue, sin duda, el salón principal, con unas dimensiones de 11 metros y medio de largo, unos 8 metros de ancho y 8 de alto, con dos ventanas y sendos balcones, ocho puertas y ocho ventanas, una chimenea con las armas del duque de Lerma por remate y "una messa de piedra negra". ${ }^{74}$ Se prosiguió con el inventario de la escalera que arranca en el lado oriental de la principal, todavía hoy visible, que permitía la entrada al patio de la cisterna a través de un aposento previo. También se tasó la cocina, uno de los cubos anexos a la escalera principal, el mismo patio de la cisterna y, lo que más nos interesa, el cuarto del duque de Lerma. ${ }^{75}$ Este estaba integrado por una primera sala con puerta al oratorio, el propio oratorio, una sala principal, la alcoba con ventana y balcón en uno de los cubos y ulteriores aposentos, algunos de ellos con vistas a la dehesa. Posteriormente se individuaron las habitaciones del piso superior, en los terrados, a los que se accedía mediante una escalera de caracol y donde estaban los desvanes.

Registrados y tasados los espacios que conformaban la antigua residencia medieval, los escribanos pasaron a considerar los aposentos reales, distribuidos entre los tres niveles del ala oriental con extraordinarias vistas al mar. ${ }^{76}$ Entre estas paredes se encontraba el cuarto del rey, con un primer salón de 12 metros de largo, 8 de ancho y 5 de alto, con dos balcones y una chimenea de piedra. Le seguía la alcoba de la reina, con una escalera de caracol que subía al cuarto de las damas, consecutivamente una tercera pieza con puerta a la capilla y ventana y balcón, y la misma capilla, de casi 4 metros de largo, 3 de ancho y casi 6 de alto. Posteriormente, "otra pieça que saca puerta a la alcova del Rey" con balcón, y el tocador de la reina, que disponía de cuatro balcones y ventanas con vistas al este, nordeste y norte, con una puerta de entrada a la galería y "una mesa de mármol". 77

Se alcanzaba entonces la galería, que medía 15 metros de largo y unos 5 metros de ancho y alto, con cuatro balcones y dos puertas, "dos chimeneas de piedras y una mesa de jaspe".$^{78}$ Desde la galería también podía accederse a la alcoba del rey, que tenía una ventana con reja a la capilla, balcones de hierro y otra puerta que conectaba con el retrete, con ulteriores balcones en este último espacio. ${ }^{79}$ Como ya hemos puesto de relieve, sabe-

\footnotetext{
73 Para el cuarto del príncipe véase: ADM, Dénia-Lerma, leg. 18, n. 4, ff. 2v y ss. En una memoria previa a dicha relación se apuntaba: "se tassará un aposento que ay debaxo el quarto del príncipe donde está la herramienta que se previno para el muelle, con su puerta y zerradura". ADM, Dénia-Lerma, leg. 18, n. 4, f. 26r.

${ }_{74}$ ADM, Dénia-Lerma, leg. 18, n. 4, ff. 3r-3v. En la memoria previa a esta relación se apuntaba: "se tassará el salón principal del castillo con todas las puertas que tiene y ventanas altas, la messa de piedra y las piedras de la chimenea, poniendo la largaria, altura y anchura". ADM, Dénia-Lerma, leg. 18, n. 4, f. 26v. Dadas sus grandes dimensiones, en el salón principal del palacio la compañía de Melchor de Villalba representó una comedia durante la primera visita del rey Felipe III a Dénia. Fue el viernes 12 de febrero de 1599. GAUNA, Felipe de, 1926-1927 [1599], vol. 1, p. 94.

${ }_{75}$ Para el cuarto del duque de Lerma, véase: ADM, Dénia-Lerma, leg. 18, n. 4, ff. 4r y ss. En la memoria previa se señalaba: "se tassará la sisterna y todo lo que mira al quarto llamado del duque, especificando la primera quadra de su entrada y el aposento que esta a la mano izquierda, llamado oratorio del duque, su sala principal con la alcova que está al cubo y luego los aposentos que ay a mano derecha con que durmieron los señores D. Vicente y D. Pasqual de Aragón en el hospedaje del señor duque de Arcos con todas sus puertas y ventanas, zerraduras, fallevas y frontijas, marcos y enserados y subiendo por la escalerilla deste quarto se an de tassar todos los aposentos que ay encima del, individuando la largaria y anchura de cada uno de por sí, con sus puertas y zerraduras y luego los terrados que caen encima de los aposentos deste quarto". ADM, Dénia-Lerma, leg. 18, n. 4, f. $26 \mathrm{v}$.

76 Para los aposentos reales, véase: ADM, Dénia-Lerma, leg. 18, n. 4, ff. 5 r y ss.

77 En la memoria se advertía: "luego la quinta pieça, que sale a la entrada de la galería, llamada el tocador de la Reyna y saca ventana al levante, al gregal y a la tramontana. En esta pieça ay una messa de mármol". ADM, Dénia-Lerma, leg. 18, n. 4, f. $26 \mathrm{v}$.

${ }_{78}$ ADM, Dénia-Lerma, leg. 18, n. 4, ff. 5v-6r. Sin embargo, en la memoria se apuntaba: "luego siguientemente la galería, con otra messa de mármol". ADM, Dénia-Lerma, leg. 18, n. 4, f. 27r.

79 Según la memoria, en el retrete se custodiaba otra mesa de mármol: "siguientemente el aposento que ay después de la galería, zerrado de cancel de madera, llamado el retrete del Rey y en él ay otra mesa de mármol". ADM, Dénia-Lerma, leg. 18, n. 4, f. 27 .
} 
mos que la galería del rey y el resto de aposentos interconectados del tercer nivel estaban situados justo debajo de la terraza con el antepecho de piedra y el estandarte. A la terraza se subía por medio de una "escalera castellana" y tenía unas dimensiones de 26 metros de largo y más de 5 de ancho. ${ }^{80}$ No obstante, resulta complicado conocer la ubicación exacta de cada una de estas habitaciones reales en la ampliación oriental de palacio, que conformaban "el quarto principal del castillo" según los escribanos. ${ }^{81}$

Es incluso más confuso el emplazamiento del último de los cuartos inventariados, donde estuvo aposentado el duque de Ariscot [¿de Aarschot?] en una fecha cercana a la relación de $1647 . .^{82}$ Se llegaba a los entresuelos de este cuarto a través de la misma escalera castellana que articulaba la terraza con la galería. Posiblemente fueron habitaciones privadas del duque de Lerma, pues algunos de sus aposentos tenían ventanas y puertas a la capilla de palacio. Más aún, la tercera de las piezas de este cuarto estuvo ocupada por la cama del duque de Lerma y estaba conectada a través de una puerta con la alcoba del rey. ${ }^{83}$ Se referenció también un pasadizo que iba desde el salón hasta el cuarto de la reina y un corredor con tres arcos de piedra que tenía dos puertas, una en la tercera pieza del cuarto y otra en uno de los cubos de la residencia. Asimismo, en el interior del palacio había dos patios con cisternas, que recogían el agua llovediza, y posteriores habitaciones en los cubos y en niveles superiores, como los doce aposentos del cuarto de las damas. Finalmente se tasaron los tejados y terrados de toda la casa, terminando con la valoración económica de los jardines del rey y el duque de Ler- ma. ${ }^{84}$ El montante final de todas las obras llevadas a cabo por el duque de Lerma en el castillo de Dénia alcanzó las 43.462 libras valencianas y 1 sueldo.

Hemos comprobado cómo la descripción de algunas de estas estancias incorporó la mención de algunos de los bienes muebles que se encontraban de puertas adentro. ¿Cómo fue el despliegue de estos ajuares domésticos en época del duque de Lerma? La respuesta la encontramos nuevamente en los inventarios de bienes coetáneos y posteriores a la muerte del duque. El primero de los registros de bienes de cuya existencia tenemos constancia es un inventario de la artillería del castillo de Dénia del 22 de julio de 1613, al que sucedieron dos años después otras noticias y asientos de armas y municiones para la fortaleza. ${ }^{85}$ No obstante, la primera relación de los bienes custodiados en el interior de la casa es más tardía, del 20 de febrero de 1616, cuando Jofré de Blanes, gobernador de Dénia, inventarió las alhajas del oratorio. ${ }^{86}$ Presidía la estancia un retablo grande de San Francisco, guarnecido de nogal, con las armas del duque de Lerma labradas en él y una cortina de tafetán verde que lo cubría. También se encontraron en este oratorio privado diferentes frontales de altar con las armas del duque y otros utensilios necesarios para la celebración de misas, como casullas, corporales, albas, purificadores, un cáliz y patena de plata con el escudo de Lerma, un portapaz, un crucifijo, una hostiera de nogal, un atril, un misal, etc. y un ara de mármol blanco encajada en el altar. Ese mismo día se hizo también inventario de los bienes del salón del palacio, donde se hallaron en diferentes estantes 300 picas, 200 arcabuces "con sus flascos y moldes para hazer pelotas" y 100 mosquetes también con flascos, moldes y forquillas, que habían sido

80 "El terrado de ensima la galería. Tiene çiento y diezyseys palmos de largo y de ancho veynte y tres y medio, con su antepecho de pedra fuerte y quatro bolas de dicha piedra". ADM, Dénia-Lerma, leg. 18, n. 4, f. 8r.

81 ADM, Dénia-Lerma, leg. 18, n. 4, f. 27r.

82 "Luego se començará a tasar el quarto en que estava aposentado el duque de Ariscot, entrando del salón por el patinejo, y en primer lugar se tasarán los entresuelos que este quarto tiene con ventanas a la capilla con su escalera, puertas, y ventanas y zerraduras, especificando lo que cada uno tiene de alto, ancho y largo". ADM, Dénia-Lerma, leg. 18, n. 4, f. 27r. Para su descripción y tasación: ADM, Dénia-Lerma, leg. 18, n. 4, ff. 6r y ss.

83 "Luego siguientemente la primera pieça que haze entrada a este quarto y luego la segunda que saca puerta a la capilla y luego la tercera en donde tuvo la cama el duque, que saca puerta a la alcova del Rey, y otra al corredor de mediodía, especificando la calidad de cada una. Este quarto tiene otra salida al salón, zerrada con un cancel de madera donde tuvo su recámara el señor duque de Arcos, que se a de tasar y medir en la misma forma que en las demás". ADM, Dénia-Lerma, leg. 18, n. 4, f. 27 r.

${ }^{84}$ ADM, Dénia-Lerma, leg. 18, n. 4, ff. 8r-8v. La memoria anterior hace también mención de unos jardines que se hicieron junto al cuarto del príncipe y en la pendiente este de la plataforma, así como de la dehesa situada en el norte de la colina, una tierra acotada destinada a actividades cinegéticas. ADM, Dénia-Lerma, leg. 18, n. 4, f. 27v.

85 El inventario de 1613 fue publicado en: SESER, Rosa, 2013, pp. 82-83. Puede consultarse en: ACCV, Protocolos, Francesc Dionís Cercós 20.765. Del 30 de mayo de 1615 es una noticia según la cual se entregó al castillo de Dénia cierta artillería a expensas del rey Felipe III. El 2 y el 16 de julio de ese mismo año se enviaron más municiones, esta vez desde el castillo de Bèrnia. ACCV, Protocolos, Francesc Dionís Cercós 20.767.

${ }^{86}$ Suponemos que se trataría del oratorio del cuarto del duque de Lerma. Véase en: ACCV, Protocolos, Francesc Dionís Cercós 20.768 . 
entregadas por "la Generalidad de Valencia" al "dicho don Jofré de Blanes con poder de su excelencia el duque de Lerma, de lo qual hizo obligación dicho don Jofré de Blanes de restituir todas las susodichas armas o pagar la valor dellas" ${ }^{87}$ Las labores de catalogación de los bienes de la residencia prosiguieron un mes después, el 23 de marzo, día en que confesó Pablo Palmir, "sotacalde del castillo de la ciudad de Dénia", tener en su poder y cargo por potestad de Jofré de Blanes:

Trenta y siete quadros colgados en la galerilla del castillo de la ciudad de Dénia, los quales embió don Carlos Coloma, visorey de la ysla de Mallorca, con una nave de Antich Jofré de Mallorca, los quales quadros están muy bien guarnecidos de madera y sobre ella dorados las guarnisiones y para clavalles en la pared con clavos dorados, los quales retratos son esta forma: tres mapas, el una del Reyno de Valencia con las armas de su Magestad y del duque mi señor con una dedicatoria a su excelencia, la otra de la isla de Mallorca y Reyno con las armas reales con las armas de los duques, padre y hijo, mis señores, con una dedicatoria a cada uno, y la otra de la ciudad de Mallorca, el otro Palacio del gran Rey de la China, otro la almadrava de Cáliz, otro de la costa de Cascays, la batalla que dio el marqués de Santa Cruz a Felipe Estresio, y otros de naufragios y los demás hasta treynta y siente son villas, ciudades, casas de Italia y Flandes, payses con verduras y otros nevados, que no tienen título. ${ }^{88}$

A estos primeros 37 cuadros enviados por Carlos Coloma de Saa, virrey de Mallorca entre 1611 y 1617 , se sumó poco después una ulterior pintura para la galería, también remitida por Coloma, aunque esta vez se trataba de una obra religiosa: "el qual quadro está muy bien guarnesido de madera dorada la guarnisión, el qual retrato es quando San Pedro sacó la moneda del tributo de la aganya del pescado". ${ }^{89}$ No es casualidad que tanto las tareas de inventariado de los ajuares de la casa como la llegada de nuevos bienes muebles fueran actuaciones coetáneas a la intensa campaña constructiva que se estaba desarrollando en Dénia. Parece evidente la intención de tales operaciones: equipar y acondicionar la residencia de Lerma según las necesidades y predilecciones del rey y su valido. De este modo, a las alhajas del oratorio, las armas del salón y las pinturas de la galería se añadieron en 1617 posteriores enseres. El 9 de enero se abonaron 200 libras valencianas al carpintero Cristóbal Reyes "por las manufaturas de seys bufetes de nogal, seys bancos de respaldar y desiseys banquillos de mano, todos con las armas de su excelencia enbutidas y perfiles de boix"..$^{90}$ Asimismo, un mes más tarde, el 12 de febrero, Pablo Palmir volvía a firmar una carta de poder y custodia de cierto mobiliario del castillo, esta vez: "quatro mesas de piedras, las tres de xaspe enbutidas y labradas y la una asul sin ninguna lavor, con sus pies de madera y el un pie de la misma color de la mesa asul de piedra, las quales a enviado [en blanco] con dos galeras de Génova para el castillo de la ciudad de Dénia". ${ }^{91}$ Por último, en la misma galería real donde fueron colgados los 38 cuadros enviados por Carlos Coloma se exhibían también "quatre retratos de la armada naval", al menos desde el 27 de mayo de 1617, cuando se costearon 200 medios pinchos para instalar dichas pinturas. ${ }^{92}$

No volvemos a tener noticias del rico menaje del palacio hasta mucho tiempo después, en 1620, cuando el duque de Lerma ya había perdido el favor del rey y la jornada en Dénia se había definitivamente malogrado. El 1 de abril de 1620 el nuevo

87 ACCV, Protocolos, Francesc Dionís Cercós 20.768.

${ }^{88}$ ACCV, Protocolos, Francesc Dionís Cercós 20.768. Tales temáticas deben ponerse en relación, sin duda, con las descripciones de ciudades y otros países presentes en los inventarios de los años 1616-1617 del palacio ducal de Lerma, tan características del gusto de la época. CERVERA VERA, Luis, 1967b, pp. 27-29. Asimismo, también se utilizaron pinturas de este tipo para la decoración de los palacios reales en España, entre cuyos inventarios encontramos numerosas referencias durante los siglos XVI y XVII. LÓPEZ TORRIJOS, Rosa, 2015, pp. 13-33.

89 La noticia es del 1 de enero de 1617, cuando Pablo Palmir confesaba nuevamente tener en su poder y cargo dicho cuadro para la galería del palacio. El 31 de diciembre de ese mismo año se pagaron a Esteban del Mas, patrón, 40 reales castellanos por fletar dicha pintura en Mallorca con destino a Dénia. ACCV, Protocolos, Francesc Dionís Cercós 20.769.

90 ACCV, Protocolos, Francesc Dionís Cercós 20.769. El 29 de octubre de 1616 se pagaron 30 libras a Blas Gavilà, carpintero, por 32 piezas de nogal para hacer bufetes y escabeches, que después serían labradas, suponemos, por dicho Reyes. ACCV, Protocolos, Francesc Dionís Cercós 20.768.

91 ACCV, Protocolos, Francesc Dionís Cercós 20.769. Es posible que fuesen mesas de piedras duras, tres de jaspes de colores con pies de madera y la azul de lapislázuli o paragone con pie de piedra, regaladas por algún gran mandatario italiano, como pudo ser el gran duque de Florencia. Como hemos visto, en 1647 todavía se conservaban estas mesas, referenciadas como "de mármol", "de jaspe" y "de piedra negra". Sobre las colecciones de objetos de piedras duras del duque de Lerma, véase: GONZÁLEZ-PALACIOS, Alvar, 2001, pp. 24-26.

92 Se compraron a Francesc Climent, carpintero. Ya había en dicha galería 700 tachuelas y 140 pinchos largos para tal efecto. ARV, Mestre Racional, n. 11.648, f. 542r. Por otra parte, justo un año antes, el 27 de mayo de 1616 se habían adquirido 20 clavos para colgar cuadros, presumiblemente para las pinturas llegadas desde Mallorca. ACCV, Protocolos, Francesc Dionís Cercós 20.768. 
sotalcaide del castillo de Dénia, Bartolomé Lloret, hizo inventario de los bienes allí custodiados "para descargo de los oficiales que entran y salen de él y que dichos bienes se sean conservados y no puedan ser escondidos". ${ }^{93}$ En la galería real de palacio todavía se encontraban los 38 cuadros enviados por el virrey de Mallorca, es decir, las 37 vistas de ciudades flamencas, italianas y españolas, países, marinas y mapas y el cuadro religioso de San Pedro tomando del pescado la moneda para el tributo del Templo. Junto a estas pinturas fueron hallados los cuatro lienzos antes mencionados de la armada naval, aquí inventariados como "de la batalla naval", enrulados en un palo y con sus cuatro marcos a parte. Asimismo, esta espaciosa pieza real también estaba ocupada por el nuevo mobiliario de nogal, las cuatro mesas de piedras duras ${ }^{94}$ y 50 marcos de madera para encerados. Además, en el salón de palacio todavía se guardaban las armas del inventario de 1616, así como un lamparón, un tambor, celosías de la tribuna de la iglesia y un estandarte con las armas del duque de Lerma. De esta misma manera, en la capilla del palacio se registraron las mismas alhajas que había en el oratorio en 1616, trasferidas a este espacio posiblemente debido a la futura visita real. Por último, durante este día y en jornadas posteriores se hizo inventario de la artillería y municiones del castillo.

Más aún, es posible seguir el rastro de todo este patrimonio hasta la segunda mitad del siglo XVII con la ayuda de nuevos asientos de bienes. En un inventario del 8 de enero de 1622 el conjunto de bienes permanecía inalterable, mientras que en el sucesivo del 10 de septiembre de 1643 la gran novedad fue la ausencia de los cuatro lienzos de la armada naval sin marcos, ${ }^{95}$ que pudieron pasar a engrosar las colecciones reales tras la muerte de Lerma. Sin embargo, el más prolijo de los inventarios del siglo XVII es la ya citada relación de 1647 , que además incluye la tasación de cada uno de los bienes catalogados. ${ }^{96}$ Como ya hemos visto, en 1647 las cuatro mesas de piedras duras estaban repartidas entre el salón principal del palacio -donde se encontraba la mesa azul/negra-, el tocador de la reina, la galería y el retrete del rey. Por lo que atañe a las pinturas, ${ }^{97}$ estaban presentes un total de 39 cuadros, es decir, el retablo de San Francisco de la capilla y los 38 restantes llegados desde MaIlorca. El principal cambio respecto a documentos anteriores es, por una parte, su tasación en libras valencianas $y$, por otra, la identificación del tema de algunos de ellos. La obra que fue tasada con un valor más elevado fue un "San Andrés de mano flamenca" (156 libras), llegando a triplicar el valor de otras pinturas, como el retablo de la capiIla (54 libras). No sabemos si fue identificado erróneamente el San Pedro y la moneda del tributo con el San Andrés de origen flamenco, o si esta última fue una incorporación más tardía, pues el resto de pinturas son seguramente los 37 cuadros de vistas de ciudades flamencas, italianas y españolas, países, marinas y mapas inventariados en 1616. Podemos identificar en la relación de 1647 los mapas del Reino de Valencia, la isla de Mallorca y la ciudad de Mallorca; el cuadro del Palacio del gran rey de la China; dos vistas de Cádiz; ocho países sin determinar; dos cuadros altos y estrechos de "arboledas y lexos"; la ciudad de Granada; la ciudad de Nápoles; la ciudad de Danrunda [?]; la ciudad de Vena en Andauzina [?]; una tormenta; un cuadro de galeras y un castillo; dos cuadros de nevadas; la ciudad de Pésaro; la ciudad de Adén; un cuadro de una pelea de navíos; un cuadro de un puerto pintado en la noche; un puerto con dos galeras; la ciudad de Marsella; un cuadro de Averena [¿Amberes?]; un cuadro "a modo de las Indias"; un San Andrés; un cuadro de "rosan buch" [?]; un cuadro de una quema; un cuadro de "pies" [?]; y un cuadro de "mala" [?]. ${ }^{98}$ Todavía en 1658 sabemos que había en el castillo de Dénia "treynta y ocho quadros con sus marcos dorados, grandes y chicos", posiblemente los Ilegados desde Mallorca, algunos de los muebles de

93 ACCV, Protocolos, Francesc Dionís Cercós 20.772.

94 "Quatro bufetes de piedra jaspis garnesidos".

95 Estos dos inventarios pueden consultarse en: ADM, Dénia-Lerma, leg. 17, n. 19, sin foliar. El inventario original de 1643 se encuentra en: ADM, Dénia-Lerma, leg. 17, n. 45. Hemos exceptuado la consideración de la artillería, municiones y otros enseres debido a la limitada extensión del trabajo.

96 ADM, Dénia-Lerma, leg. 18, n. 4. Antonio Gastaldo y Cosme Traver, maestros obreros de la villa, fueron los encargados de evaluar las obras arquitectónicas y su mobiliario interior, otros personajes como Juan Martorell, pintor, Pedro Benast, platero, Jacinto del Olmo, sastre, y Onufrio Ramón, artillero, fueron requeridos para proporcionar las respectivas relaciones de pintura, plata, prendas de vestir y artillería legadas por Lerma.

97 ADM, Dénia-Lerma, leg. 18, n. 4, ff. 16v y ss.

98 El total de la tasación de los cuadros ascendía hasta las 1.175 libras. ADM, Dénia-Lerma, leg. 18, n. 4, f. 17v. Hemos usado interrogantes con aquellos cuadros cuya identificación temática no está clara, seguramente porque carecían de títulos, provocando que los escribanos se equivocaran con la toponimia de lugares extranjeros y representaciones de temas desconocidos. La estimación de estas pinturas fluctuó entre las 10 y las 47 libras valencianas. 
nogal y las cuatro mesas de piedras duras. ${ }^{99}$ Por último, en un memoria de 1661 de los bienes, rentas y derechos que tenía el marqués de Dénia en esta ciudad aún se apuntaba: "tiene su excelencia en el castillo de dicha ciudad un palacio adornado de payses y bufetes jaspeados"; 100 es decir, aquellos ricos ajuares que décadas antes habían sido instalados en la reformada residencia del duque de Lerma en Dénia con la intención de dar alojamiento digno al rey Felipe III y su Corte. ¿Con qué fin? La desde hacía tanto tiempo anhelada visita que nunca llegaría a efectuarse.

\section{Bibliografía}

ARCINIEGA GARCÍA, Luis. "Construcciones, usos y visiones del Palacio del Real de Valencia bajo los Austrias". Ars Longa, 2005-2006, n 14-15, pp. 129-164.

ARCINIEGA GARCÍA. Luis. "Carrera profesional del maestro de obras del rey en el Reino de Valencia en época de los Austrias: la sucesión al cargo que ocupó Francisco Arboreda en 1622". Ars Longa, 2009, n 18, pp. 109-132.

BUSTAMANTE GARCíA, Agustín. "Los artífices del Real Convento de la Encarnación, de Madrid". Boletín del Seminario de Estudios de Arte y Arqueología: BSAA, 1975, tomo 40-41, pp. 369-388.

CABRERA DE CÓRDOBA, Luis. Relaciones de las cosas sucedidas en la corte de España desde 1599 hasta 1614. Madrid: Imprenta de J. Martín Alegría, 1857.

CAMPOS-PERALES, Àngel. "La estatua marmórea del duque de Lerma en el castillo de Dénia, obra de Giuseppe Carlone". Archivo Español de Arte, octubre-diciembre 2018a, XCl, n 364, pp. 395-410.

CAMPOS-PERALES, Àngel. "La compra de la Casa de la Huerta, sus jardines, búcaros, porcelanas y vidrios de San Juan de Ribera por el duque de Lerma". En: GÓMEZ-FERRER, M.; GIL SAURA, Y. (eds.). Ecos culturales, artísticos y arquitectónicos entre Valencia y el Mediterráneo en Época Moderna. Valencia: Universitat de València, 2018b, pp. 309-327.

CERVERA VERA, Luis. El conjunto palacial de la villa de Lerma. Valencia: Editorial Castalia, 1967a.

CERVERA VERA, Luis. Bienes muebles en el palacio ducal de Lerma. Valencia: Editorial Castalia, 1967b.

CHABÁS, Roque. Historia de la ciudad de Denia. Dénia: Imprenta de Pedro Botella, 1876, II tomos.

GARCÍA, Eugenio; SEBASTIÁN, Ramón. Análisis histórico del testamento del duque de Lerma, quinto marqués de Dénia. Dénia: Ajuntament de Dénia, 1983.

GARCÍA GARCÍA, Bernardo J. "Apostillas históricas". En: VEGA, Lope de. Fiestas de Denia. Introducción y texto crítico de M.G. Profeti. Florencia: Alinea, 2004 [1599], pp. 31-62.

GARCÍA GARCÍA, Bernardo J. "Espacios de la privanza. Las residencias del favorito como extensión de los Reales Sitios en tiempos del duque de Lerma (15991618)". En: GARCÍA GARCÍA, B. J. (ed.). Felix Austria.
Lazos familiares, cultura política y mecenazgo artístico entre las cortes de los Habsburgo. Madrid: Fundación Carlos de Amberes, 2016, pp. 393-440.

GAUNA, Felipe de. Relación de las fiestas celebradas en Valencia con motivo del casamiento de Felipe III. Edición de Salvador Carreres Zacarés. Valencia: Acción Bibliográfica Valenciana, 1926-1927 [1599], 2 vols.

GIL SAURA, Yolanda. "La tapicería de la expulsión de los moriscos. Un proyecto frustrado de Rodrigo Calderón". Locus amoenus, 2018, n²16, pp. 133-153.

GÓMEZ-FERRER, Mercedes. El Real de Valencia (12381810). Historia arquitectónica de un palacio desaparecido. Valencia: Institució Alfons el Magnànim-Diputació de València, 2012.

GONZÁLEZ-PALACIOS, Alvar. "Puentes de piedras duras. Relaciones entre España e Italia". En: GONZÁLEZPALACIOS, A. (com.). Las colecciones reales españolas de mosaicos y piedras duras (Catálogo de la exposición celebrada en Madrid, Museo Nacional del Prado, 2001). Madrid: Museo Nacional del Prado, 2001, pp. 19-43.

IVARS, Josep. Dénia, la ciutat $i$ el castell: I'arquitectura militar baluardada (segles XVI-XIX). Dénia: Ajuntament de Dénia; Valencia: Universitat de València, 2015.

LÓPEZ TORRIJOS, Rosa. "Las 'galerías de ciudades' en el siglo XVI". En: LÓPEZ TORRIJOS, R. et al. Representar la ciudad en la Edad Moderna: 1565. Wyngaerde en Alcalá. Madrid: UNED, UAH y IEC, 2015, pp. 13-33.

MARTÍ Y MONSÓ, José. Estudios histórico-artísticos relativos principalmente a Valladolid basados en la investigación de diversos archivos. Valladolid-Madrid: Leonardo Miñón, 1898-1901.

MORÁN, Miguel; PORTÚS, Javier. El arte de mirar. La pintura y su público en la España de Velázquez. Madrid: Istmo, 1997.

PALAU, Marco Antonio. Diana desenterrada. Antiguas memorias y breve recopilación de los más notables sucesos de la ciudad de Denia, desde su antiquísima fundación hasta el estado presente. Alicante: Diputación Provincial, 1975 [1643].

PALAU DIEGO, Francisco. El Llobarro: anales de Denia y su comarca. Pedreguer: La Marina Alta, 1983.

PÉREZ SÁNCHEZ, Alfonso E. "Un lienzo de Pedro Juan de Tapia en el Prado". Boletín del Museo del Prado, 1991, vols. 12-14, pp. 7-12.

RUÍZ ALCÓN, María Teresa. "Pinturas y otros objetos". Reales Sitios, 1976, n 47, pp. 18-24.

SÁNCHEZ GONZÁLEZ, Antonio (ed.). El arte de la representación del espacio. Mapas y planos de la colección Medinaceli. Huelva: Universidad de Huelva, 2017.

SCHROTH, Sarah. The private picture collection of the Duke of Lerma. Tesis doctoral. New York University: UMI, Dissertation Services, 1990.

SESER, Rosa. La ciutat de Dénia en temps del Duc de Lerma. Dénia: Ajuntament de Dénia, 2013.

VILLALMANZO, Jesús. "La colección pictórica sobre la expulsión de los moriscos. Autoría y cronología". En: ARDIT, M. et al. La expulsión de los moriscos del Reino de Valencia. Valencia: Fundación Bancaja, 1997, pp. 34-69.

99 El inventario es del 20 de mayo de 1658: ADM, Dénia-Lerma, leg. 17, n. 19, sin foliar. Aunque no se menciona explícitamente el retablo de San Francisco, es posible que todavía se conservase en esta fecha, ya que en dicho inventario se referenció "una cortina de tafetán verde, vieja, con que se cubre el retablo".

100 ADM, Dénia-Lerma, leg. 18, n. 20. 